Prepared for the U.S. Department of Energy

under Contract DE-AC05-76RL01830

\title{
Implementation Plan for the Deep Vadose Zone-Applied Field Research Center
}

$\begin{array}{ll}\text { DM Wellman } & \text { RE Gephart } \\ \text { MJ Truex } & \text { MB Triplett } \\ \text { MD Freshley } & \text { TC Johnson }\end{array}$

February 2011

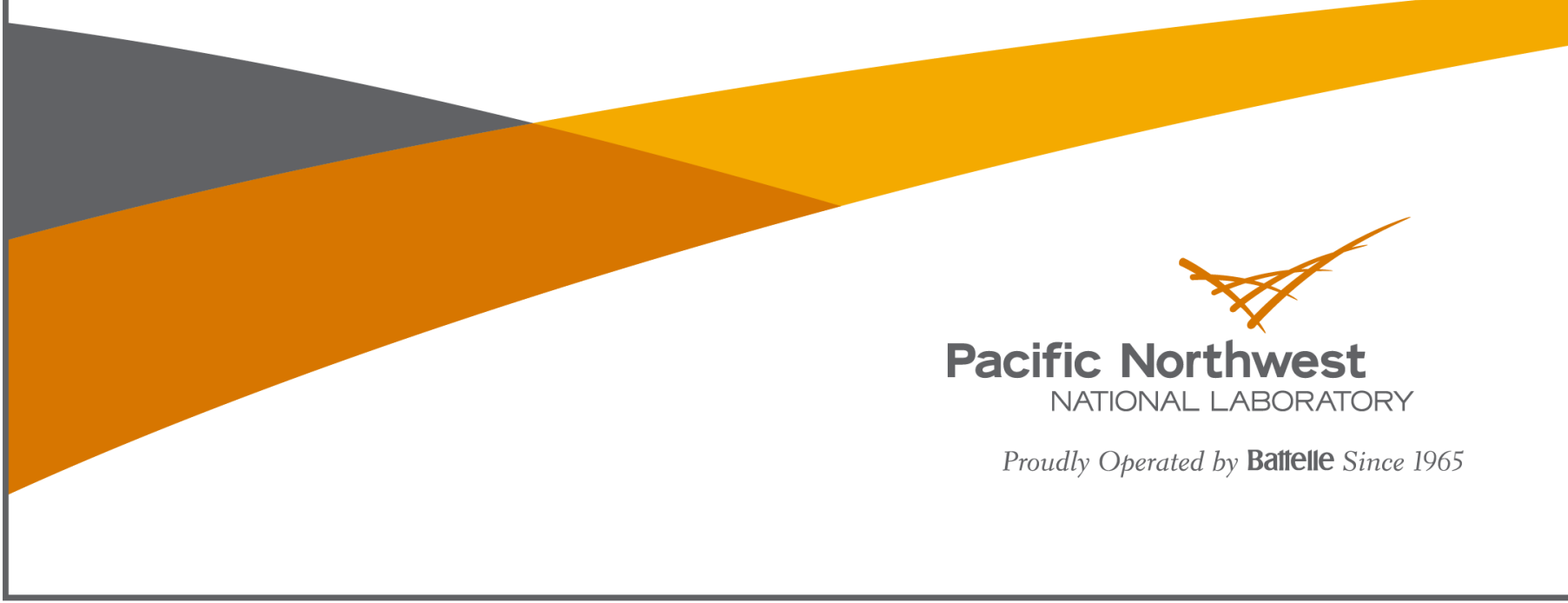




\title{
DISCLAIMER
}

This report was prepared as an account of work sponsored by an agency of the United States Government. Neither the United States Government nor any agency thereof, nor Battelle Memorial Institute, nor any of their employees, makes any warranty, express or implied, or assumes any legal liability or responsibility for the accuracy, completeness, or usefulness of any information, apparatus, product, or process disclosed, or represents that its use would not infringe privately owned rights. Reference herein to any specific commercial product, process, or service by trade name, trademark, manufacturer, or otherwise does not necessarily constitute or imply its endorsement, recommendation, or favoring by the United States Government or any agency thereof, or Battelle Memorial Institute. The views and opinions of authors expressed herein do not necessarily state or reflect those of the United States Government or any agency thereof.

\author{
PACIFIC NORTHWEST NATIONAL LABORATORY \\ operated by \\ BATTELLE \\ for the \\ UNITED STATES DEPARTMENT OF ENERGY \\ under Contract DE-ACO5-76RL01830
}

Printed in the United States of America
Available to DOE and DOE contractors from the Office of Scientific and Technical Information,
P.O. Box 62, Oak Ridge, TN 37831-0062;
ph: (865) 576-8401
fax: (865) 5765728
email: reports@adonis.osti.gov

\author{
Available to the public from the National Technical Information Service, \\ U.S. Department of Commerce, 5285 Port Royal Rd., Springfield, VA 22161 \\ ph: (800) 553-6847 \\ fax: (703) 605-6900 \\ email: orders@nits.fedworld.gov \\ online ordering: http://www.ntis.gov/ordering.htm
}




\section{Implementation Plan for the Deep Vadose Zone-Applied Field Research Center}

$\begin{array}{ll}\text { DM Wellman } & \text { RE Gephart } \\ \text { MJ Truex } & \text { MB Triplett } \\ \text { MD Freshley } & \text { TC Johnson }\end{array}$

February 2011

Prepared for

the U.S. Department of Energy

under Contract DE-AC05-76RL01830

Pacific Northwest National Laboratory

Richland, Washington 99352 


\section{Executive Summary}

The Long-Range Deep Vadose Zone Program Plan was published in October 2010 (DOE-RL 2010). It summarized the U.S. Department of Energy's (DOE's) state-of-knowledge about the contaminant remediation challenges facing the deep vadose zone (DVZ) beneath the Central Plateau of the Hanford Site and their approach to solving those challenges.

Developing an implementation plan is the next step to address the knowledge and capabilities required to solve DVZ challenges. This multi-year plan (covering FY-11 through FY-20) identifies the near- to long-term research, management, and execution plans undertaken by the DVZ-Applied Field Research Center (DVZ-AFRC) to solve those problems.

The schedule supporting DVZ-AFRC implementation overlies existing activities and milestones from Hanford's DOE-Environmental Management (EM) end-user projects. Success relies upon multi-project teams, focused on coordinated subsurface projects undertaken across the DOE Complex, combined with facilitated, problem-targeted, research investments implemented through the DVZ-AFRC. The implementation plan is divided into three principal sections:

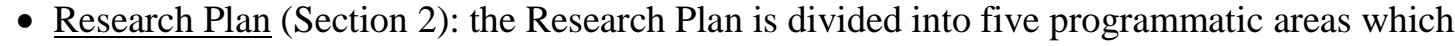
includes four research and development categories (Research Design, Controlling Processes, In situ Characterization and Monitoring, and Predictive Modeling and Data Integration) and the National Deep Vadose Zone Program. Each addresses critical lines of inquiry and associated goals, outcomes, deliverables, and collaborations. Deliverables cover the near-term (FY-11 to 12), intermediate term (FY-13 to 15), and long-term (FY-16 to 20).

- Management Plan (Section 3): the Management Plan covers the organizational structure for the DVZAFRC, including roles, responsibilities, operations, and partnerships with DOE Offices, site contractors, and others.

- Execution Plan (Section 4): the Execution Plan summarizes work scope descriptions, products and capability delivered schedules, budgets, and how progress is tracked and monitored.

The Implementation Plan contains one appendix providing waste site summary descriptions for the major vadose zone contamination problem areas within the Inner Area of the Hanford Site. This Inner Area is the current focus area and test bed for DVZ-AFRC activities. These descriptions summarize the nature of the contamination problem, current activities supporting the four research categories supported by the DVZ-AFRC, and how those activities are integrated with the Hanford Site remediation schedule. 


\section{Acronyms and Abbreviations}

\begin{tabular}{|c|c|}
\hline AFRC & Applied Field Research Center \\
\hline ASCEM & Advanced Simulation Capability for Environmental Management \\
\hline CERCLA & Comprehensive Environmental Response, Compensation, and Liability Act \\
\hline CHPRC & CH2M Hill Plateau Remediation Company \\
\hline CMS & Corrective Measures Study \\
\hline DOE & U.S. Department of Energy \\
\hline DOE-RL & U.S. Department of Energy, Richland Operations Office \\
\hline DQO & Data Quality Objective \\
\hline DVZ & Deep Vadose Zone \\
\hline EA & Enhanced Attenuation \\
\hline EM & U.S. Department of Energy, Office of Environmental Management \\
\hline EPA & U.S. Environmental Protection Agency \\
\hline EVMS & Earned-value Management System \\
\hline IFRC & Integrated Field Research Challenge \\
\hline MNA & Monitored Natural Attenuation \\
\hline ORP & U.S Department of Energy, Office of River Protection \\
\hline OTID & U.S. DOE Office of Technology Innovation and Development \\
\hline PNNL & Pacific Northwest National Laboratory \\
\hline PNSO & U.S. Department of Energy Pacific Northwest Site Office \\
\hline RCRA & Resource Conservation and Recovery Act \\
\hline REDOX & Reduction Oxidation \\
\hline $\mathrm{RI} / \mathrm{FS}$ & Remedial Investigation/Feasibility Study \\
\hline RFI/CMS & RCRA Facility Investigation/Corrective Measures Study \\
\hline SAP & Sampling and Analysis Plan \\
\hline $\mathrm{SC}$ & U.S. Department of Energy Office of Science \\
\hline SESP & Subsurface Environmental System Sciences Program \\
\hline SFA & Science Focus Area \\
\hline SST & Single-shell Tank \\
\hline WMA & Waste Management Area \\
\hline WRPS & Washington River Protection Solutions \\
\hline
\end{tabular}




\section{Contents}

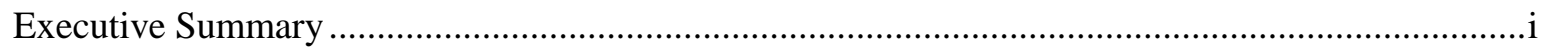

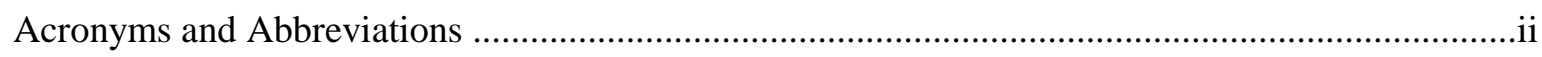

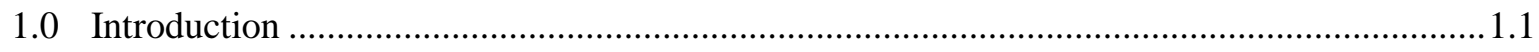

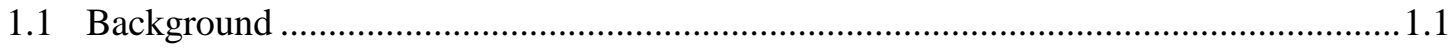

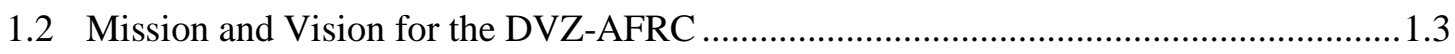

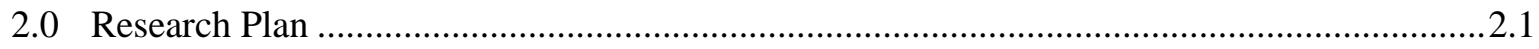

2.1 DOE Complex Challenges and Hanford DVZ Target Problems..................................2.1

2.2 Programmatic Agenda, Goals, and Outcomes............................................................. 2.5

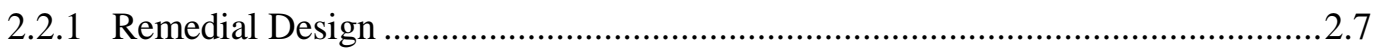

2.2.2 Controlling Processes ............................................................................2.10

2.2.3 In situ Characterization and Monitoring ......................................................2.12

2.2.4 Predictive Modeling and Data Integration .................................................2.15

2.2.5 National Deep Vadose Zone Program ............................................................2.16

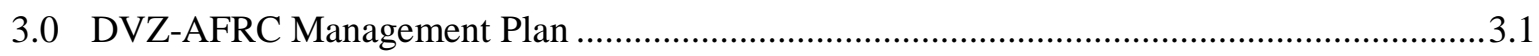

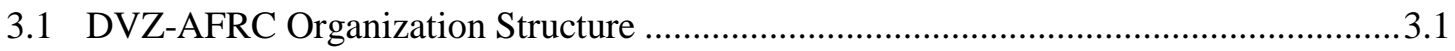

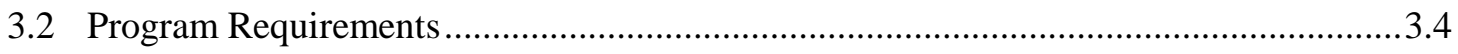

3.3 Partnerships with Other DOE Offices, Site Contractors, and Organizations ................... 3.5

3.4 Communication and External Outreach .................................................................... 3.7

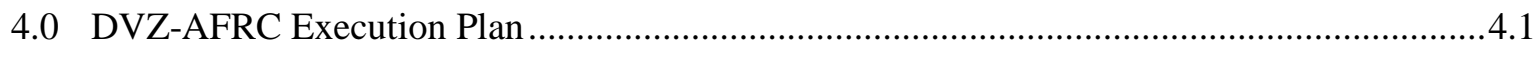

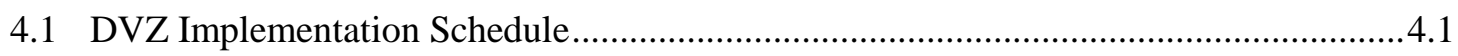

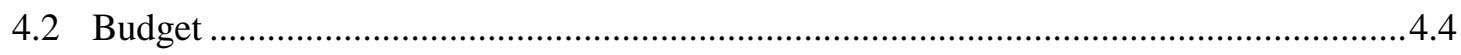

4.3 Project Performance Metrics and Monitoring ...........................................................4. 4.4

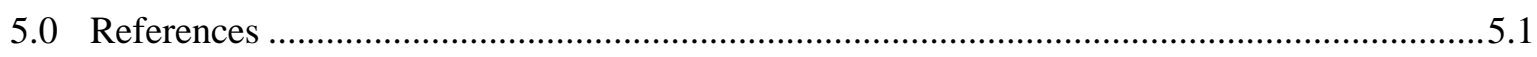

Appendix A - Deep Vadose Zone Problem Areas and Short Descriptions.....................................1 


\section{Figures}

1.1. Location of the Hanford Site and Central Plateau .................................................................. 1.2

2.1. Inner Area of the Central Plateau Showing Examples of DVZ Problem Areas ......................... 2.5

3.1. Organization Chart for the DVZ Applied Field Research Center ............................................ 3.1

3.2. Linkage of Use-Inspired Basic Research and Applied Science to Support Technology

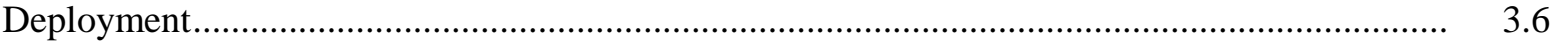

4.1. Near-Term DVZ Implementation Schedule.................................................................... 4.2

4.2. Intermediate-to Long-Term DVZ Implementation Schedule .................................................

\section{Tables}

2.1. Program Areas, Lines of Inquiry, Goals, and Outcomes for the DVZ-AFRC ............................ 2.6

3.1. Summary of Key DVZ-AFRC Staff Roles and Responsibilities ................................................

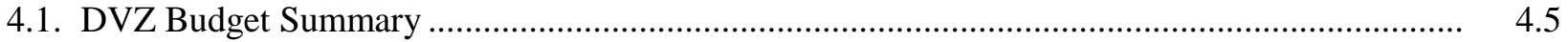




\subsection{Introduction}

Section 1.0 provides a brief introduction to the challenges faced in understanding and remediating the deep vadose zone (DVZ) contamination beneath U.S. Department of Energy (DOE) sites, particularly the Hanford Site, resulting from the past disposal of liquid waste effluents. Details about these topics are found in DOE-RL (2010). Also introduced is the mission and vision of the multi-year research and development project — the DVZ Applied Field Research Center (DVZ-AFRC) — designed to address the long-term protection of water resources at DOE-EM sites by developing and applying effective solutions for DOE's DVZ challenges in characterization, prediction, remediation, and monitoring.

\subsection{Background}

DVZ contamination is a significant issue in many regions of the United States, although much of the attention has been on arid and semiarid regions where that zone is thickest. The vadose zone is that portion of the subsurface between the land surface and the underlying water table. For the purpose of this document, the DVZ is defined as the lower portion of the vadose zone existing below the depth where remedies are applied for surface waste sites. Although the lower boundary of the DVZ is well defined, the upper boundary depends on site-specific factors.

Inorganic and radionuclide contamination remaining in the $\mathrm{DVZ}$ is isolated from the surface environment. As such, it does not pose a risk to human health or the environment. Rather, movement of contamination from the DVZ to the underlying groundwater creates the potential for exposure and therefore risk to receptors. For this reason, remediation solutions for the DVZ target groundwater protection.

The magnitude of contaminant discharge (mass per time) from the vadose zone to the groundwater must be maintained low enough by natural attenuation (e.g., adsorption processes or radioactive decay) or through remedial actions (e.g., contaminant mass or mobility reduction) to achieve and sustain groundwater protection goals. Contaminant transport mechanisms through the vadose zone can attenuate the overall contaminant flux to the groundwater; therefore, vadose zone contamination may not necessarily require remediation if the natural flux results in sufficiently low contaminant concentrations in the groundwater. In some cases, remediation undertaken to control transport, enhance attenuation mechanisms, or remove contaminants may be needed to limit flux so groundwater or surface water protection standards are maintained.

Technical challenges due to the properties of the DVZ and the paucity of suitable remediation, characterization, and monitoring capabilities complicate the decision process for DVZ remedial actions. Currently, vadose zone remediation, characterization, and monitoring approaches for metal and radionuclide contamination are largely untested and are significantly less developed than the options for shallow soil contamination or for saturated groundwater contamination. Predicting the performance of remedies, a key element supporting remedy decisions, is also relatively undeveloped and untested with respect to DVZ contamination issues. The DVZ-AFRC seeks to address these issues to support selecting and implementing effective remedies for the DVZ.

At the Hanford Site, DVZ remediation targets contamination resulting from waste disposal near the center of the Hanford Site in an area known as the Central Plateau (Figure 1.1). This area is where nearly 
a half century of spent fuel reprocessing took place. Those operations discharged large volumes of water and waste effluents into hundreds of disposal sites, including cribs, trenches, ponds, and some reverse wells. In addition, contaminated liquids leaked into the subsurface from underground single-shell waste storage tanks and associated piping. Contamination has spread into the vadose zone, and a portion of the mobile contaminants has reached groundwater. A significant portion of both mobile and relatively immobile contaminants remain in the overlying vadose zone and are a component of the potential longterm environmental risk at Hanford. The DOE-RL published The Long-Range Deep Vadose Zone Program Plan (DOE-RL 2010) to address these DVZ challenges. It summarizes DOE's state-ofknowledge about the geohydrologic setting and contaminant remediation challenges facing the DVZ beneath the Central Plateau of the Hanford Site and the approach to meeting those challenges.

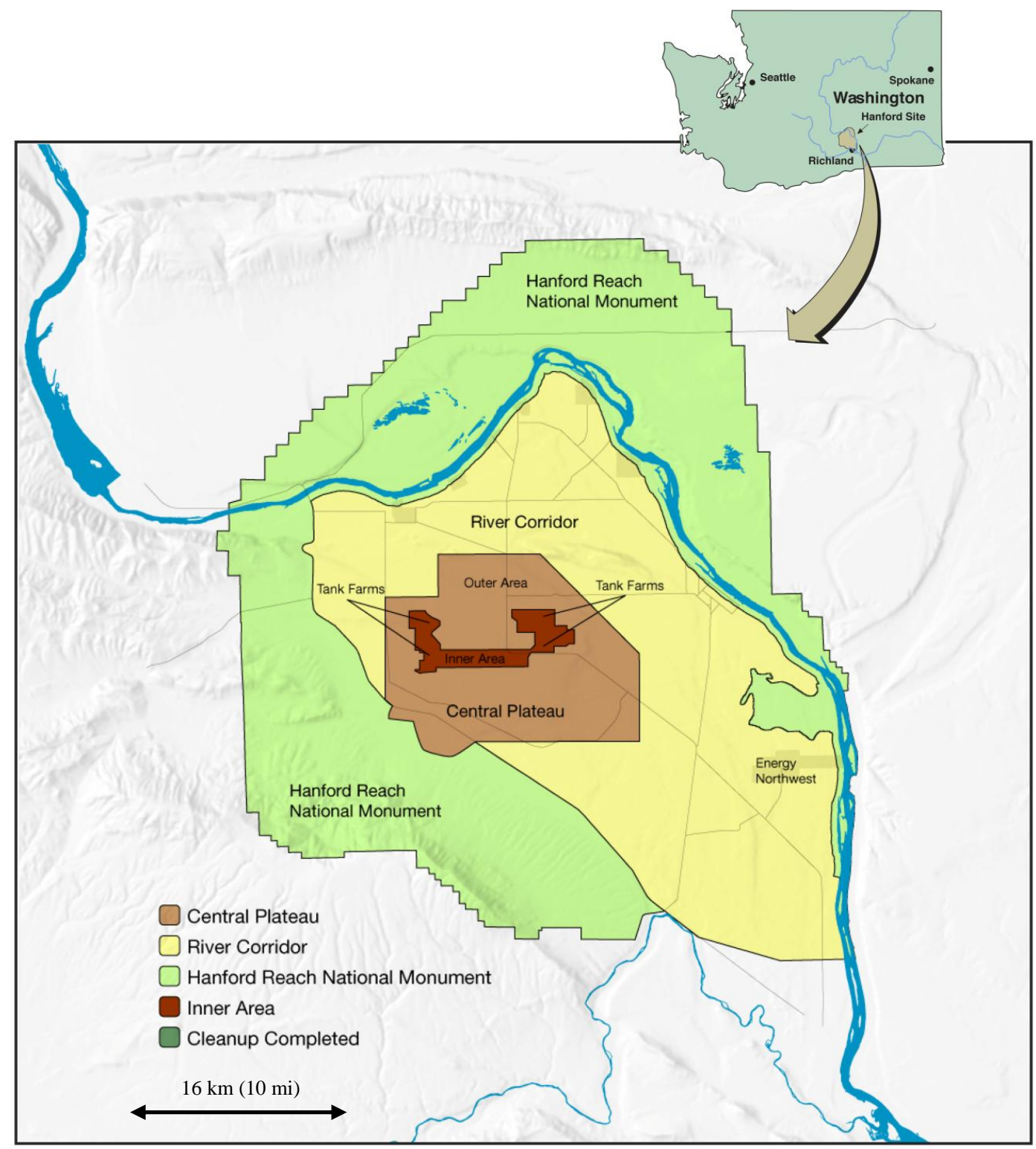

Figure 1.1. Location of the Hanford Site and Central Plateau 
DOE, the National Research Council, and others recognize that there are no immediate solutions to many DVZ contamination problems and that existing DOE Environmental Management baseline plans are not expected to provide adequate solutions to remediate DVZ environments. As reported by the National Research Council, available capabilities and approaches to characterizing, conceptually understanding, and modeling subsurface properties and contaminant-controlling processes are inefficient, insufficient, and can lead to incorrect predictions of contaminant behavior and remediation performance (NRC 2000, 2001, 2009).

Therefore, through the DVZ-AFRC and related efforts, DOE is using an approach to develop solutions at Hanford and other DOE sites that builds upon available knowledge and capabilities, leverages investments from various DOE organizations, and partners basic science, applied science, and site engineering activities.

DOE will use expertise from agency-wide activities, national laboratories, academia, and industry to work in collaboration with the Tri-Party Agreement signatories, site contractors, the public, and others to provide viable remedial technologies and strategies targeting baseline needs at Hanford and other DOE sites.

\subsection{Mission and Vision for the DVZ-AFRC}

The mission of the DVZ-AFRC is to address the long-term protection of water resources at DOE-EM sites by developing and applying effective solutions for DOE's DVZ challenges in characterization, prediction, remediation, and monitoring. At Hanford, those water resources refer to the unconfined aquifer underlying the DVZ and the Columbia River into which the aquifer discharges groundwater.

The overall vision for the DVZ-AFRC is to provide a technical basis to quantify, predict, and monitor natural and post-remediation contaminant discharge from the vadose zone to the groundwater and to facilitate developing in situ solutions that limit this discharge and protect water resources. 


\subsection{Research Plan}

The DVZ-AFRC effort will augment and complement efforts currently underway for DVZ environmental remediation with an emphasis on providing characterization, monitoring, and remediation solutions that quantify and mitigate contaminant discharge to the groundwater. Contaminant discharge from the vadose zone to the groundwater is impacted by processes that occur in the vadose zone. Basic science resources are being applied to understand these processes and their relationship to the biogeochemical and hydrologic conditions in the vadose zone. Site contractor resources are being applied to characterize the nature and extent of contaminants in the vadose zone, conduct treatability tests to quantify how technologies change the site and contaminant conditions, and evaluate remediation options. The DVZ-AFRC applied research effort integrates with these and other efforts by providing laboratoryand field-scale data with a focus on relating vadose zone process descriptions, contaminant nature and extent, and remedial treatment processes to the resultant contaminant discharge. These activities support developing site conceptual models and evaluating the long-term performance of remedies. They are also related to an EM-32 funded project to develop numerical models that facilitate the evaluation of vadose zone contaminant transport and discharge to the groundwater. This project is known as Advanced Simulation Capability for Environmental Management (ASCEM), focused on developing the next generation of performance and risk assessment models for DOE EM.

The DVZ-AFRC also includes technology development efforts to enable the application of innovative remediation strategies, improve amendment delivery processes, enhance remedy performance monitoring, and develop flux-based monitoring for the vadose zone.

Success of the DVZ-AFRC requires multi-institutional and multi-disciplinary research teams, including staff from the national laboratories, universities, industry, and other federal and state agencies. The DVZ-AFRC will be fully integrated with three other applied research centers established by the Office of Groundwater and Soil Remediation (EM-32) within the DOE Office of Technology Innovation and Development (OTID). Those centers are:

- Attenuation-Based Remedies for the Subsurface-Applied Field Research Center (Savannah River, South Carolina)

- Remediation of Mercury and Industrial Contaminants - Applied Field Research Center (Oak Ridge, Tennessee)

- Advanced Simulation Capability for Environmental Management (ASCEM).

\subsection{DOE Complex Challenges and Hanford DVZ Target Problems}

The success of any DVZ remediation technology needs to be considered within the regulatory context. Remediating the vadose zone is linked to meeting remediation goals for groundwater. As such, remediation in the vadose zone can be targeted for mitigating the source of contamination and reducing transport through the vadose zone to environmental receptors, in contrast to meeting a specific concentration measured at some location within the vadose zone. Herein lies the challenge: applying vadose zone remediation to reach an acceptable rate of contaminant transport while realizing that there are considerable uncertainties associated with estimating and measuring contaminant transport at the field scale. 
At relatively "simple" sites, obtaining sufficient remediation of the vadose zone to essentially eliminate vadose zone contamination may be a reasonably obtainable goal. At complex sites, such as the Hanford Central Plateau, residual contamination is likely for most remediation scenarios. Complete removal of contaminants dispersed in the DVZ is unattainable because of the complexities associated with the distribution and the heterogeneity of subsurface environments. Thus, a "residual" mass of contaminant will remain, even if mass removal techniques are applied, and this residual will control mass flux over the long term. The need to understand and predict contaminant transport behavior over long time scales is reinforced by estimates that more than 100 DOE sites will have remaining residual contamination at the completion of remediation programs. While there has been much recent research on measuring, estimating, and predicting mass flux, most work focused on the saturated zone (aquifer), with minimal attention to characterizing and predicting mass flux for vadose zone systems.

Two critical needs confronting deep vadose zone remediation and closure are determining the acceptable contaminant flux from the vadose zone to the groundwater receptor and devising a means to implement and monitor a flux reduction technology to reduce vadose zone contamination below levels requiring control.

A regulatory basis exists for leaving contamination in place in the vadose zone, provided flux to groundwater is limited - and monitored. Determining the acceptable level of contaminant residual to meet groundwater resource protection goals and how to appropriately measure when this residual has been attained are key challenges for setting remediation objectives in the vadose zone. However, this approach requires developing methods and protocols for predicting in situ remedial performance sufficiently to support a remedy decision. While this effort may seem daunting, acceptance of monitored natural attenuation (MNA) as a remedy for a wide range of contaminants and site settings provides a good example of how predictions of long-term remedy performance can be structured and used to support remedy selection. Techniques suitable for monitoring and managing the long-term presence of contaminants in the vadose zone are a key component of implementing flux-control remedies for the vadose zone. It is relatively straightforward to measure contaminant concentrations in groundwater, but it is far more difficult to demonstrate through monitoring and prediction that groundwater will remain uncontaminated or that contamination will remain below levels of concern in the future. Therefore, it is necessary to understand and quantify the ramifications of contaminant removal and disposition options, and develop remediation strategies, monitoring technologies and approaches, and predictive simulations for deep vadose zone remediation and protection of water resources.

A key to designing and implementing successful subsurface remedies, including monitored natural attenuation, is developing accepted predictive simulations of vadose zone contamination fate and transport. Models must be calibrated to site data and validated against monitoring to make long-term predictions of contaminant fate and transport and develop defensible remediation strategies. Simulation can be effective in reducing time and costs associated with developing remediation strategies. Relevant complexity, mobility, and attenuation processes must be included in models used to evaluate in situ remediation processes and long-term projections of contaminant fate and transport to support monitored natural attenuation.

Conditions in the DVZ have both positive and negative impacts on remediation of contaminants. Positive aspects may include the following: 
- Unsaturated flow is often slow, and incremental enhancements that reduce flow may support achievement of remediation goals.

- Due to slow movement, long times are available for contaminant interactions with sediments and remediation amendments.

- Finer grained units usually have higher water-holding/sorption capacity and hence hold more contaminants than coarser grained units.

- A large portion of the driving force for water flow comes from natural meteoric recharge and can therefore be controlled with surface caps or infiltration barriers.

- Gas-phase advection for distributing remediation amendments can be effective over large zones of influence without introducing large quantities of water.

- If water enters in relatively small quantities, its effect on the rate of contaminant movement in the DVZ may still be low.

Challenges to remediation may include the following:

- Subsurface heterogeneities in hydraulic properties can complicate the development of reliable conceptual and predictive models.

- Heterogeneity in hydraulic properties, as in the saturated zone, may cause difficulties for bringing remediation amendments in contact with contaminants or for extracting contaminants.

- Preferential liquid flow paths can vary greatly under different saturations.

- Gas-phase movement is preferential in higher permeability zones, and higher liquid saturation can reduce gas permeability.

- Contaminants held in low-permeability, finer grained materials may be harder to access for contaminant removal or treatment.

- Introducing water creates wetter conditions, so control of water distribution in unsaturated flow conditions must be considered.

- Contaminants can be mobilized and pushed ahead of added remediation solutions rather than mixing with these solutions and being treated.

- Remediation chemistry can be affected by the presence of a gas phase (e.g., $\mathrm{CO}_{2}$, oxygen) and low soil-moisture content.

- There is difficulty in characterizing large-scale hydraulic properties because of the inability to stress significant volumes of sediment.

- Monitoring the pore water for characterization/remediation can be difficult because deep pore water cannot be readily collected, and measurements may represent only a small region around the collection point.

Within the context of the vadose zone conditions, the conceptual approaches for remediation can be categorized as controlling the flux of contaminants to groundwater to meet groundwater remediation goals either through 1) contaminant mass reduction, 2) stabilization of contaminants so they move slower, or 3) manipulation to slow the movement of contaminated pore water. At the current time, however, 
vadose zone remediation approaches for metal and radionuclide contamination based on reducing the contaminant flux to groundwater are still largely in the developmental and demonstration stage.

The DVZ-AFRC Research Plan (Section 2.0) was developed to address the key issues limiting the availability of suitable DVZ remediation technologies. Target problems specific to the Hanford DVZ have been identified to focus the DVZ-AFRC activities. Transforming basic science principles into viable systems and transferring remediation technologies from groundwater, shallow vadose zone, or waste treatment applications to the DVZ will require adaptation and demonstration. Simulation is a proven approach to accelerated innovation, significantly reducing development times, and lowering costs for new approaches focused on complex systems (Koonin 2010). For years, companies such as Boeing, Ford Motor Company, and Goodyear have benefited from high-performance simulations of industrial processes through decreased test and development times, increased process capabilities, and cost savings (Dean 2010). The same benefits can hold true for advancing environmental remediation capabilities.

Appendix A provides an initial set of DVZ problem area descriptions for the Hanford Site. These descriptions briefly summarize the waste sites, the nature of the DVZ threat, and the status of current investigations, treatability studies, and related actions for each of the four research focus areas of the DVZ-AFRC: controlling processes, remedial design, in situ characterization and monitoring, and predictive modeling and data integration. Appendix A provides DVZ problem and research integration summaries for the following Hanford waste site $\operatorname{areas}^{1}$ (locations shown in Figure 2.1):

- BC Cribs and Trenches

- B Complex (Uranium)

- B Complex (Technetium-99)

- Waste Management Area C (C Single-Shell Tank [SST] Farm)

- T Complex (T, TX and TY SST Farms and surrounding waste sites)

- U Cribs

- S Complex (S and SX SST Farms and surrounding waste sites, including REDOX cribs).

\footnotetext{
${ }^{1}$ Figure 2.1 also shows the deep vadose zone carbon tetrachloride contaminant area associated with past operations of the Plutonium Finishing Plant (PFP). Appendix A does not provide a separate summary of this area because an active soil vapor extraction system has been in place since the mid-1990s. This system along with an expanded groundwater pump-and-treat system is expected to be sufficient to meet remediation goals. Enhanced deep vadose zone remediation methods are not expected to be required for this area.
} 


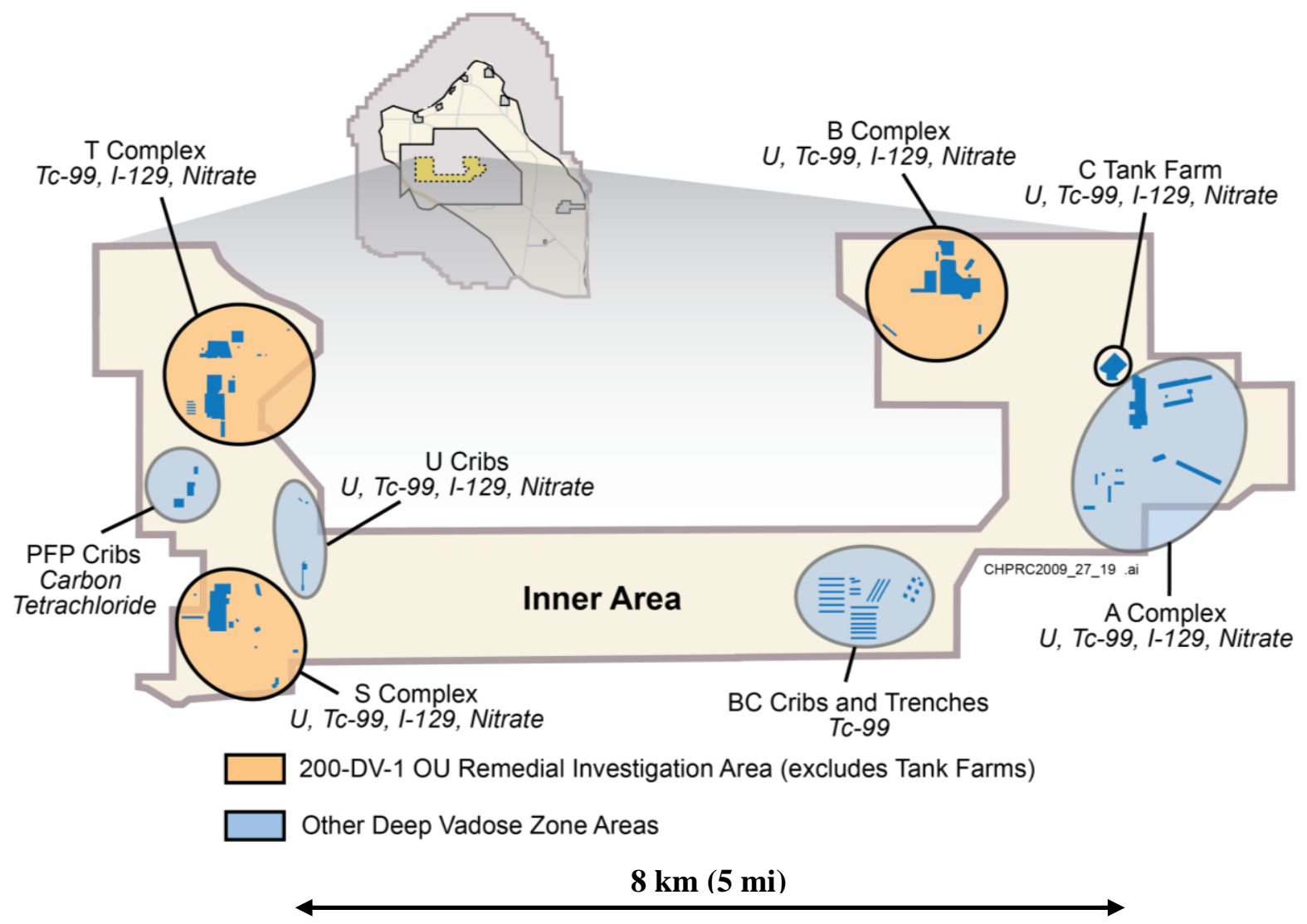

Figure 2.1. Inner Area of the Central Plateau Showing Examples of DVZ Problem Areas

\subsection{Programmatic Agenda, Goals, and Outcomes}

To support achieving remediation goals, progress is needed in five programmatic areas which include four research and development categories (remedial design, controlling processes, in situ characterization and monitoring and predictive modeling and data integration) and the national deep vadose zone program. These are discussed in Table 2.1 and Sections 2.2.1 through 2.2.5. Each subsection outlines critical lines of inquiry, outcomes, goals, and proposed research and technology development activities covering the near-term (FY-11 to 12), intermediate-term (FY-13 to 15) and long-term (FY-16 to 20). 
Table 2.1. Program Areas, Lines of Inquiry, Goals, and Outcomes for the DVZ-AFRC

\begin{tabular}{|c|c|}
\hline \multicolumn{2}{|c|}{$\begin{array}{l}\text { R\&D Development Category 1. Remedial Design-Perform applied research to broaden the suite of } \\
\text { remedies available for DVZ contamination and enhance the technical basis for evaluating DVZ remedy } \\
\text { effectiveness, implementability, and cost. }\end{array}$} \\
\hline \multirow[t]{4}{*}{$\begin{array}{l}\text { Critical Lines of } \\
\text { Inquiry and } \\
\text { Associated Goals }\end{array}$} & $\begin{array}{l}\text { Innovative technology screening-Evaluate the scientific and technical defensibility } \\
\text { and efficacy of emerging technologies and identify promising technologies requiring } \\
\text { further development. }\end{array}$ \\
\hline & $\begin{array}{l}\text { Applied remediation development - Research and develop innovative technologies } \\
\text { and methodologies to improve the ability to access and remediate the DVZ and } \\
\text { evaluate remediation effectiveness, implementation, and cost. }\end{array}$ \\
\hline & $\begin{array}{l}\text { Advanced amendment delivery-Research advanced and minimally invasive } \\
\text { delivery mechanisms to more effectively deliver reactive agents into the deep } \\
\text { subsurface. }\end{array}$ \\
\hline & $\begin{array}{l}\text { Long-term effectiveness of potential remedies-Develop technically defensible data } \\
\text { and methodologies to evaluate how potential technologies will perform over long } \\
\text { periods, particularly for technologies that leave contaminants in place. }\end{array}$ \\
\hline Outcomes & $\begin{array}{l}\text { Advanced remedial strategies to effectively address low permeability zones, mitigate } \\
\text { the flux of contaminants (e.g., Tc, U) from vadose zone environments to } \\
\text { groundwater, and meet long-term plume remediation goals. }\end{array}$ \\
\hline \multicolumn{2}{|c|}{$\begin{array}{l}\text { R\&D Development Category 2. Controlling Processes-Quantify coupled hydrologic, geochemical, } \\
\text { and microbial processes functioning in the DVZ to developing reliable conceptual models of moisture } \\
\text { flux, contaminant movement, and remediation process efficacy in DVZ environments. }\end{array}$} \\
\hline \multirow[t]{3}{*}{$\begin{array}{l}\text { Critical Lines of } \\
\text { Inquiry and } \\
\text { Associated Goals }\end{array}$} & $\begin{array}{l}\text { Long-term stability of remediation end states - Quantify biogeochemical and } \\
\text { hydrogeological processes and heterogeneities that control contaminant behavior and } \\
\text { remedial performance to provide advanced conceptual and predictive models. }\end{array}$ \\
\hline & $\begin{array}{l}\text { Dominant transport pathways-Identify key geo-stratigraphic-controlled } \\
\text { contaminant flow pathways that govern moisture/contaminant flux and remediation } \\
\text { amendment movement in the subsurface at waste sites. }\end{array}$ \\
\hline & $\begin{array}{l}\text { Discontinuity impacts on flow, transport, and contaminant fate during } \\
\text { remediation activities-Develop approaches to quantify the impact that subsurface } \\
\text { heterogeneities and anisotropic conditions have on moisture flow and contaminant } \\
\text { transport. }\end{array}$ \\
\hline Outcomes & $\begin{array}{l}\text { Perform applied research to } 1 \text { ) better design remedial strategies; 2) reduce } \\
\text { unintended consequences from treatment processes; } 3 \text { ) provide a technical basis for } \\
\text { transitioning from active remediation to monitored natural attenuation; and 4) } \\
\text { improve predictive capabilities for contaminant fate and transport. }\end{array}$ \\
\hline \multicolumn{2}{|c|}{$\begin{array}{l}\text { R\&D Development Category 3. In situ Characterization and Monitoring-Characterize the } \\
\text { distribution of geochemical and hydrologic properties governing contaminant transport; monitor } \\
\text { subsurface behavior, contaminant movement, and remediation performance. }\end{array}$} \\
\hline \multirow[t]{3}{*}{$\begin{array}{l}\text { Critical Lines of } \\
\text { Inquiry and } \\
\text { Associated Goals }\end{array}$} & $\begin{array}{l}\text { Access and Characterization Techniques-Develop enhanced access and in situ } \\
\text { characterization techniques allowing efficient characterization of biogeochemical } \\
\text { and hydrogeologic properties. }\end{array}$ \\
\hline & $\begin{array}{l}\text { Remediation Monitoring Techniques-Develop advanced technologies and } \\
\text { methodologies to provide effective and appropriate monitoring of plume behavior } \\
\text { and remedial emplacement and performance within the DVZ. }\end{array}$ \\
\hline & $\begin{array}{l}\text { Early-warning Thresholds of Unexpected Performance-Establish the basis for } \\
\text { early-warning monitoring "thresholds" of unexpected or unacceptable DVZ } \\
\text { behaviors, such as changes in moisture flow and contaminant movement. }\end{array}$ \\
\hline
\end{tabular}


Table 2.1. Program Areas, Lines of Inquiry, Goals, and Outcomes for the DVZ-AFRC

\begin{tabular}{|c|c|}
\hline & $\begin{array}{l}\text { Flux-based Monitoring for the Vadose Zone-Develop novel methods for } \\
\text { monitoring fluxes within the vadose zone. }\end{array}$ \\
\hline Outcomes & $\begin{array}{l}\text { Provide capabilities to accurately refine subsurface DVZ remedial performance } \\
\text { through monitoring and accurately evaluating both predictive tools and remedial } \\
\text { action impacts on subsurface system; establish basis for early warning monitoring } \\
\text { "thresholds" of unexpected or unacceptable DVZ behavior, such as changes in } \\
\text { moisture flow and contaminant movement. }\end{array}$ \\
\hline \multicolumn{2}{|c|}{$\begin{array}{l}\text { R\&D Development Category 4. Predictive Modeling \& Data Integration-Simulate the integrated } \\
\text { processes controlling moisture flux, contaminant transport, and remediation performance. }\end{array}$} \\
\hline \multirow[t]{2}{*}{$\begin{array}{l}\text { Critical Lines of } \\
\text { Inquiry and } \\
\text { Associated Goals }\end{array}$} & $\begin{array}{l}\text { Deep Vadose Zone Process Models-Develop calibrated models to predict the } \\
\text { mobility of risk-driving contaminants and their reactive transport for the range of } \\
\text { waste, geochemical, and hydrological conditions pertinent to DVZ natural } \\
\text { attenuation or engineered remediation. This line of inquiry will be addressed } \\
\text { through collaboration with ASCEM. }\end{array}$ \\
\hline & $\begin{array}{l}\text { Facilitate development and utilization of remediation technology performance } \\
\text { modeling to support feasibility studies. }\end{array}$ \\
\hline Outcomes & $\begin{array}{l}\text { Provide scientific and technology information to support the Comprehensive } \\
\text { Environmental Response, Compensation, and Liability Act of } 1980 \text { (CERCLA) fate } \\
\text { and transport assessments of long-term performance for remedial alternatives and } \\
\text { reduce remedial design development and implementation times by applying } \\
\text { simulation capabilities. }\end{array}$ \\
\hline \multicolumn{2}{|c|}{$\begin{array}{l}\text { National DVZ Program-Transfer and communicate the scientific basis of cleanup or stewardship } \\
\text { decisions to stakeholders, those who are or could be affected by the consequences of vadose zone } \\
\text { contamination and by the decisions made by problem owners and regulators. }\end{array}$} \\
\hline \multirow[t]{3}{*}{$\begin{array}{l}\text { Critical } \\
\text { Activities and } \\
\text { Associated Goals }\end{array}$} & $\begin{array}{l}\text { Scientific and Public Acceptance of DVZ Remediation Strategies-Provide the } \\
\text { foundational framework to consider the risk and challenges for remediating DVZ } \\
\text { environments and the efficacy of technologies in achieving regulatory goals. }\end{array}$ \\
\hline & $\begin{array}{l}\text { Compilation of DVZ Remediation Technology, Closure, and Transition Decisions } \\
\text { Guidance-Provide better tools for supporting site-wide assessments and decisions } \\
\text { on environmental cleanup and stewardship. }\end{array}$ \\
\hline & $\begin{array}{l}\text { State of Practice for Understanding and Technologies-Advance the current } \\
\text { knowledge and capabilities that already exist in the research communities into } \\
\text { operational use at the nation's priority sites of vadose zone contamination. }\end{array}$ \\
\hline Outcomes & $\begin{array}{l}\text { Transfer the framework for addressing DVZ challenges in characterization, } \\
\text { monitoring, predictive simulation, and remediation that were built and exemplified at } \\
\text { Hanford to other sites within the DOE Complex facing similar challenges as well as } \\
\text { federal agencies and local entities with responsibility for cleanup of contaminated } \\
\text { sites, including regulatory agencies (the U.S. Environmental Protection Agency } \\
\text { [EPA], various state regulatory agencies, etc.). }\end{array}$ \\
\hline
\end{tabular}

\subsubsection{Remedial Design}

Previous efforts, such as the Deep Vadose Zone Treatability Test Plan for the Hanford Central Plateau (DOE-RL 2008), identified candidate technologies for DVZ remediation and needs for additional technology development and testing. Ongoing efforts for the Hanford 200-DV-1 operable unit also include technology screening. In summary, while there are a number of candidate vadose zone 
remediation technologies, they are largely untested and are significantly less developed than the options for shallow soil contamination or for saturated groundwater contamination. Due to the properties of the vadose zone, delivering remediation amendments is a key development issue for active remediation of the vadose zone. However, the vadose zone properties are also conducive to contaminant retention and slow release to the groundwater. Therefore, natural attenuation and technologies that enhance attenuation mechanisms are prime candidates for further investigation. For all of the candidate remediation approaches, data to support the prediction of remedial long-term effectiveness, a key element supporting remedy decisions, is also relatively undeveloped and untested with respect to candidate DVZ remedies.

The remedy design programmatic area of the DVZ-AFRC is intended to advance the state of knowledge for DVZ remediation and to work in concert with the ongoing remedial investigation/feasibility study (RI/FS) efforts for the Hanford 200-DV-1 operable unit. It will provide technical and technology information that broadens the suite of remedies available for DVZ contamination and enhances the technical basis for evaluating DVZ remedy effectiveness, implementability, and cost. In outyears, efforts will also include support related to technical issues with remedy implementation. The following activities are planned for remedy design:

Near-term (FY-11 to 12): Initial activities will include support to the technology evaluation for 200$\mathrm{DV}-1^{2}$, including identifying candidates for additional applied research. Ongoing efforts associated with developing foam delivery methods will be continued and integrated with related foam efforts in the 1) In situ Characterization and Monitoring and 2) Predictive Modeling programmatic areas. Key issues undergoing investigation will be the foam transport process, interaction with candidate remedial amendments, and impacts on short- and long-term contaminant transport. Activities will also include an engineering evaluation of candidate vadose zone delivery and access methods for aqueous, gas, and particulate amendments for use in augmenting the evaluation of candidate remediation approaches. Previous Hanford DVZ treatability testing examined some of the potential remediation amendments. Additional laboratory-scale experiments will be initiated to build on this effort to provide input to the screening of potential technologies. Natural attenuation processes are expected to be important for controlling contaminant flux to groundwater. Activities will include compiling a technical basis for conducting a monitored natural attenuation (MNA) evaluation for DVZ contaminants. This activity will provide a structure for incorporating efforts in the Controlling Processes and Predictive Modeling programmatic areas related to natural attenuation into an evaluation of monitored natural attenuation as all or part of a remedy. The MNA activity will also provide a basis from which targets for attenuation enhancements can be evaluated.

Deliverables will support 200-DV-1 technology screening and work plan development and WMA C Corrective Measures Study:

- Technology information input to 200-DV-1 technology screening

- Identification of characterization needs for evaluating promising candidate technologies for input to the 200-DV-1 RI work plan

- Engineering evaluation of delivery and access methods (including foam delivery technology)

\footnotetext{
${ }^{2}$ Where 200-DV-1 is listed in Section 2.2, it is recognized that similar inputs may also be provided, as appropriate, to Waste Management Area C (WMA C) and to other operable units that contain known deep vadose zone waste sites. For example, the 200-WA-1 operable unit includes the BC cribs and trenches plus the U cribs which are key application areas for DVZ investigations and technology.
} 
- Framework for MNA evaluation of the Hanford DVZ.

Intermediate-term (FY-13 to 15): Evaluating delivery methods will transition from laboratory- and bench-scale to the field scale with anticipation that some testing can be conducted at uncontaminated portions of the Hanford Site. These field efforts will be coordinated with remediation monitoring activities in the In situ Characterization and Monitoring programmatic area. Laboratory evaluation of candidate remediation amendments will transition to include long-term performance testing (e.g., to establish dissolution rates of precipitates formed). Efforts related to natural attenuation processes and associated enhanced attenuation approaches will be continued. Surface barriers are expected to be an integral part of final remediation systems in many cases at Hanford and other DOE sites with vadose zone contamination. Thus, data will be collected, and surface barrier information relevant to the DVZ will be evaluated. The intermediate-term activities for the remediation design element will target the collection of information for support of the planned FY-15 200-DV-1 feasibility study.

Deliverables will support the 200-DV-1 feasibility study and the WMA C corrective measure study:

- Field test reports for delivery methods

- Long-term performance evaluation report for promising candidate technologies

- Surface barrier evaluation report

- Technical basis for evaluating MNA/enhanced attenuation (EA) for the Hanford DVZ

- Compilation of MNA/EA guidance and technical information for application to the DVZ.

Long-term (FY-16 to 20): Longer term efforts will continue to seek promising technologies but with more focus on providing information to support remedy design, implementation, performance prediction, and resolution of technical issues identified in the RI/FS effort. As necessary, field tests of delivery methods or technologies will be conducted to support remedy implementation design. In particular, remediation research will be coordinated with previous and ongoing efforts in the In situ Characterization and Monitoring, Controlling Processes, and Predictive Modeling programmatic areas related to evaluating and monitoring long-term contaminant flux to the groundwater.

Deliverables will support the 200-DV-1 remedial design and WMA C corrective measures implementation:

- Field test reports for delivery methods and remedy performance evaluation

- Evaluation report for selected technologies describing remediation performance and monitoring to support evaluation of long-term contaminant flux to the groundwater

- Compilation of DVZ remediation technology guidance and technical information.

Collaborations: Strong collaborations have been established and will be continued for the remediation design program area of the DVZ-AFRC. These collaborations include interfaces with Hanford contractor vadose zone treatability testing and characterization efforts such as those established for the desiccation field test and other 200-DV-1 operable unit activities. Key collaborators also include both Pacific Northwest National Laboratory (PNNL) and Lawrence Berkeley National Laboratory (LBNL) Science Focus Areas by investigating contaminant behavior relevant to remediation technology options and 
geophysical evaluation of remediation processes. Linkages have also been established and will be continued with ASCEM, especially related to the support of field test design and interpretation.

Collaboration with DOE-Office of Science (SC) Science Focus Areas (SFAs) and Integrated Field Research Challenges (IFRCs) and other EM-32 centers (see introduction to Section 2.0) will also be fostered. For example, improved understanding of uranium behavior from the Hanford 300 Area and the Rifle, Colorado IFRC's and the PNNL SFA may be relevant. Additionally, attenuation-based remedy information for metals and radionuclides generated from efforts under the Biogeochemical Processes for Applied Subsurface Science Center at the Savannah River Site are expected to include results that can be translated to the DVZ. Ongoing technical efforts under the EM-32 vadose zone-focused projects have also established collaborations that will be continued. For instance, foam delivery development and vadose zone organic research tasks have included collaboration with LBNL, MSE Technology Applications, Inc. (MSE), Camp Dresser \& McKee, Inc. (CDM), Oregon State University, Washington State University, Louisiana State University, and the University of Arizona. These research tasks have also included linkages to the EPA-Office of Research and Development and the U.S. Army Corps of Engineers to make results more nationally available.

\subsubsection{Controlling Processes}

Hydrologic conditions and biogeochemical transformations are subsurface controlling mechanisms that depend upon the physical, biological, and chemical setting of the site and contaminants. Quantifying and establishing linkages between hydrologic, geochemical, and microbial processes functioning in the DVZ are critical to developing reliable, conceptual models of moisture flux and contaminant movement and successful remediation approaches. This knowledge enables a better definition of the level of remediation. Moreover, understanding these controlling processes is critical to developing new and costeffective in situ remediation technologies, such as chemical and biological reduction, physico-chemical sorption-precipitation, and monitored natural attenuation and long-term stewardship of contaminated sites.

New, cost-effective technologies for remediating the DVZ must rely on processes such as chemical and biological reduction, physico-chemical sorption-precipitation, and natural attenuation. Natural attenuation processes are expected to be important for controlling contaminant flux to groundwater. Activities will include compiling a technical basis for conducting a monitored natural attenuation evaluation for DVZ contaminants. This monitored natural attenuation activity will provide a structure for incorporating efforts in the Controlling Processes and Predictive Modeling programmatic areas related to natural attenuation into an evaluation of MNA as all or part of a remedy.

To implement in situ remedies, new knowledge regarding the subsurface processes controlling water movement and contaminant transport is needed. Research in this area of interest will provide: 1) better design of remedial strategies; 2) reduction of unintended consequences from treatment processes; 3) a technical basis for transitioning from active remediation to monitored natural attenuation; and 4) improved predictive capabilities for contaminant fate and transport. These outcomes will provide information to help the Hanford Site and other DOE sites that have DVZs meet specific regulatory milestones associated with the CERCLA and RI/FS processes and impact site milestones.

The following activities will be implemented to advance the understanding of DVZ controlling processes: 
Near-term (FY-11 to 12): The DVZ-AFRC will examine contaminated sediments from beneath waste sites to quantify hydrogeophysical and biogeochemical heterogeneous controls on contaminant and water flux. This includes quantifying predictions of ion exchange and precipitation fronts required to describe geochemical reactions between contaminants and in-earth materials and remediation process reactions to factor reactive transport analyses into predictive models. The DVZ-AFRC will couple new, low-invasive geophysical tools with controlled laboratory/field test bed experiments to identify the fundamental relationships between geophysical responses of differing contaminant plume distributions and moisture content. An additional facet of this effort includes maximizing sample collection opportunities and initiating long-term preservation of samples for research and technology development use.

Deliverables will support the 200-DV-1 remedial investigation and WMA C RCRA facility investigation:

- Evaluate controlling processes for delivery and access methods (including foam delivery technology)

- Support the development of T Complex and S Complex conceptual models (200-DV-1)

- Implement Hanford DVZ sample archive for preservation of samples to support future science and technology

- Support the development of waste management area (WMA) A-AX data quality objectives (DQOs) and sampling and analysis plans (SAPs) for Resource Conservation and Recovery Act (RCRA) Facility Investigation

- Provide framework for MNA evaluation of the Hanford DVZ.

Intermediate-term (FY-13 to 15): In addition to near-term activities to further our understanding of controlling process, the effect of co-disposed contaminants on contaminant behavior and fate will be evaluated, and the understanding applied to support remedy selection, implementation, and long-term monitoring. Additional intermediate activities will focus on evaluating and quantifying the contaminant mass flux from the vadose zone to the groundwater to support remedy selection and implementation. This will include examining the isotopic composition of shallow to DVZ pore water for insight into contaminant sources, behavior, and processes that affect radionuclide transport and mobility.

Deliverables will support the 200-DV-1 feasibility study and the WMA C corrective measures study:

- Acquire and analyze Hanford sediment samples: U-8/U-12 cribs, T and S complex, and supplemental characterization boreholes (200-DV-1)

- Characterize and evaluate coupled processes resulting from co-contamination

- Initiate characterization of microbial processes in Hanford DVZ sediments

- Provide technical basis for evaluating MNA/EA for the Hanford DVZ.

Long-term (FY-16 to 20): Long-term controlling process activities will focus on evaluating and quantifying the contaminant mass flux from the vadose zone to the groundwater to support long-term monitoring. Methods will be developed to directly measure and validate deep contaminant migration rates and moisture fluxes beneath waste sites and undisturbed locations. An integrated systems-level (micro- to field-scale) conceptual simulation framework will be developed that integrates best available information describing vadose zone characteristics, contaminants, and reactive transport processes 
encompassing waste sites to Central Plateau scales. This will include identifying key geostratigraphiccontrolled contaminant flow pathways that control moisture/contaminant flux and remediation amendment movement in the subsurface at waste sites.

Deliverables will support the 200-DV-1 RI/FS activities and tank farm corrective actions:

- Characterization of microbial processes in Hanford DVZ sediments

- Field test reports for remedy performance evaluation

- Evaluation report for selected technologies describing remediation performance and monitoring to support evaluation of long-term contaminant flux to the groundwater

- Compilation of DVZ remediation technology guidance and technical information.

Collaborations: The controlling process program area will continue to build upon the strong collaborations that have been established. These collaborations include interfaces with Hanford contractor vadose zone treatability testing and characterization efforts such as those established for the desiccation field test and other 200-DV-1 operable unit activities. Key collaborators also include both PNNL and LBNL SFAs by investigating contaminant behavior relevant to remediation technology options and geophysical evaluation of remediation processes. Linkages have also been established and will be continued with ASCEM, especially related to support of conceptual model development and predictive simulation of remediation activities. Collaboration with DOE-SC SFAs, IFRCs, and other EM32 centers (see introduction to Section 2.0) will also be fostered. For example, improved understanding of uranium behavior from the Hanford 300 Area and Rifle IFRC's and the PNNL SFA may be relevant. Additionally, this program area is currently working with DVZ-AFRC researchers at Oregon State University to visualize the arrangement of fluid in unsaturated sediments and quantify the role of geochemical and hydrogeologic heterogeneities on the transport and fate of technetium in unsaturated environments. Additional collaborations are being established with the University of Notre Dame and will be expanded as necessary to accomplish the programmatic goals.

\subsubsection{In situ Characterization and Monitoring}

Developing techniques to effectively characterize persistent vadose zone contaminants and controls on contaminant flux is critical to develop defensible conceptual site models, quantify contamination and moisture flux, reasonably estimate future contaminant flux to the groundwater, and implement effective monitoring strategies. Near real-time monitoring techniques are needed to monitor remedy emplacement, allow remedy distribution strategies to be optimized during application, facilitate the selection of appropriate technologies and application methods, and provide independent validation of predictive model simulations. Long-term monitoring techniques are needed to verify remedial performance over time, provide early warning measures of unexpected or unacceptable behaviors, and reduce performance monitoring and life-cycle costs.

Contaminant mass flux from the vadose zone to the groundwater will be the primary metric for selecting and implementing remedies. The characterization focus will be on developing approaches for investigating the controls on contaminant and water flux, including the distribution of hydrologic and biogeochemical heterogeneities. A near real-time monitoring effort will focus on developing and testing minimally invasive 4D geophysical imaging techniques to monitor the emplacement of remedial reagents. 
And long-term monitoring efforts will focus on developing robust DVZ sensor/sampling technologies and analysis for assessing long-term remedial performance in terms of flux to groundwater. This includes natural marker monitoring systems or devices which are integrated into the surrounding environmental matrix (e.g. subsurface, groundwater, surface water) and are responsive to and/or reflect alterations brought about by natural processes or remediation activities. These provide critical early warning capabilities to identify the spatial distribution of unexpected and or unacceptable processes such as moisture flow and contaminant mobilization.

The characterization and monitoring element of the DVZ-AFRC is intended to support the ongoing RI/FS efforts for the Hanford 200-DV-1 operable unit by providing enhanced capability to understand site-specific DVZ conditions to effectively evaluate potential remedial technologies through treatability testing. Characterization and monitoring technologies developed by the DVZ-AFRC will broaden the suite of capabilities available and enhance the technical basis for evaluating DVZ remedy effectiveness, implementability, and cost. In outyears, efforts will also include support technology transfer efforts related to implementing and operating DVZ characterization and monitoring systems.

The following activities will be implemented to address DVZ characterization and monitoring needs:

Near-term (FY-11 to 12): The DVZ-AFRC will conduct a detailed review of existing and emerging technologies that meet or potentially meet DVZ characterization and monitoring needs. This includes identifying the technical challenges inhibiting the applicability or practicality of technologies otherwise well-suited for DVZ environments. The DVZ-AFRC will identify the most promising characterization and monitoring technologies and will initiate further development and applied research to address impeding technical challenges. This may include improving DVZ access technologies (e.g., less expensive drilling or direct push modifications), adapting sensors for robust DVZ deployment, enhancing high-performance geophysical modeling and inversion codes, and implementing combined technologies. Promising "field ready" technologies warranting further testing will be queued for demonstration and validated during field-scale treatability testing. Such testing is already underway using high-performance, time-lapse, electrical resistivity imaging, ground penetrating radar, temperature, and matric potential monitoring at the BC Cribs desiccation treatability test site. In addition, advanced geophysical methods are being investigated to monitor foam and gas-phase amendment delivery, soil vapor extraction, and associated processes.

Deliverables will support the 200-DV-1 RI/FS, treatability testing, WMA C RFI/CMS activities, and tank farm interim barrier deployments:

- Identify and evaluate potential DVZ characterization and monitoring technologies

- Input into 200-DV-1 RI/FS characterization and monitoring technology screening effort

- Identify and evaluate improved access technologies such as direct-push for DVZ sensor array installation

- Develop/modify high-performance geophysical modeling and inversion codes for near real time imaging of DVZ processes

- Apply and evaluate ground penetrating radar, temperature, matric potential, and time-lapse electrical resistivity/induced polarization imaging at the BC-Cribs desiccation treatability test site 
- Investigate and develop advanced geophysical methods to monitor foam and gas phase amendment delivery and soil vapor extraction

- Provide input into S-SX interim barrier monitoring plan.

Intermediate-term (FY-13 to 15): In addition to a continuation of near-term characterization and monitoring research and development activities, intermediate-term activities will focus on field deployment, demonstration, and validation of promising technologies identified and developed to address DVZ remediation needs. This includes instrumenting uncontaminated analog sites for testing and validating monitoring approaches before deployment into treatability testing scenarios. The DVZ-AFRC will also test enhanced access methods that enable the transition of validated monitoring technologies to the DVZ. Geophysical characterization and monitoring technology transfer will be initiated by integrating high-performance modeling and inversion codes into the ASCEM framework.

Deliverables will support the 200-DV-1 RI/FS, treatability testing, WMA C RFI/CMS activities, and tank farm interim barrier deployments:

- Field test reports for DVZ characterization and monitoring technologies

- Field test reports for advance access methods and sensor installation technologies

- High-performance geophysical modeling and inversion modules for the ASCEM framework.

Long-term (FY-16 to 20): Long term characterization and monitoring activities depend to a large extent on the utility of characterization and monitoring technologies developed and tested in the near and intermediate terms. During this phase, technologies will be further refined based on lessons learned during previous testing, and prepared for full deployment. Monitoring technologies implemented in the near-term (i.e., desiccation treatability testing monitoring technologies) will be evaluated and reviewed for effectiveness as long-term monitoring technologies.

Deliverables will support the 200-DV-1 remedial design and WMA C corrective actions:

- Field test reports for long-term monitoring of DVZ treatability test sites

- Input into 200-DV-1 remedial design (and WMA C Corrective Measures Implementation plan)

- Input into 200-DV-1 (and BC-1 and WMA C) remedy design and long-term monitoring plan.

Collaborations: DVZ-AFRC in situ characterization and monitoring efforts will build upon collaborative relationships in place for several DOE EM-32 and DOE-SC sponsored projects. Site contractors, PNNL, and LBNL are currently collaborating to test in situ characterization and monitoring approaches at the BC-Cribs desiccation field treatability tests. PNNL, LBNL, and MSE are collaborating to investigate and develop advanced geophysical methods for monitoring foam emplacement and subsequent remedial processes. High-performance geophysical modeling and inversion codes developed under the Hanford 300 Area IFRC are being modified by PNNL to make use of geophysical research conducted by LBNL. These codes will integrate with the ASCEM code to provide wider use and applicability throughout the DOE Complex. Hanford Site contractors and PNNL are collaborating to investigate the potential of using electrical geophysical techniques to monitor gas-phase amendment injection and pore-water extraction remediation techniques. The DVZ-AFRC will also collaborate with contractors employing characterization and monitoring techniques within the tank farm areas. These 
collaborations will be fostered to provide a wide base of expertise in AFRC in situ characterization and monitoring efforts.

\subsubsection{Predictive Modeling and Data Integration}

The DVZ-AFRC includes predictive models to integrate site characterization data with science and technology information. Predictive models using these data will evaluate the performance of remedial strategies and facilitate the development of the scientific foundation, applied technologies, and strategic direction for meeting remediation goals in a manner that is technically defensible and acceptable to regulators. The DVZ-AFRC applies models to assist with remediation design, including development of models to describe remediation processes, such as foam delivery, for which models do not presently exist. The project will rely on ASCEM for long-range model development and support. As part of the development process, ASCEM includes a series of demonstrations to test model components and provide refinement feedback. These demonstrations are being implemented through a series of working groups. The Hanford Site BC Cribs and Trenches working group will be used to link ASCEM with the DVZAFRC.

Near-term (FY -11 to 12): Activities will focus on supporting the RI/FS work planning process for the vadose zone operable units. Modeling will support remediation design activities such as soil desiccation testing and surface barrier emplacement. Site modeling activities are underway using existing simulators (e.g., Subsurface Transport Over Multiple Phases-STOMP) and supported by laboratory investigations of modeling parameters and processes. The DVZ-AFRC is focused on process-model development, specifically a model for foam transport and delivery. This process model is being developed from theoretical foundations and laboratory experimentation and will be a subroutine or module that can be incorporated into existing simulators such as STOMP and ASCEM as the new capability is developed. ASCEM will continue to interface with Hanford DVZ efforts through the working group and demonstration of capabilities. The DVZ working group is formulating approaches for 2011 activities, but likely will focus on evaluating alternative conceptual models and uncertainty analysis related to contaminant source identification. High performance computing (HPC) capabilities will be coming online that can be used for simulating vadose zone flow and transport processes.

Deliverables will support fate and transport model activities for 200-DV-1 RI and WMA C RCRA facility investigation:

- Foam transport and other modules for incorporation into ASCEM

- DVZ working group collaborations with ASCEM for BC cribs and trenches

- Alternative conceptual models and uncertainty analysis for supporting site characterization, remediation design, and monitoring

- Maintain interface with Hanford Site fate and transport modeling used to develop screening values for subsurface contaminant concentrations protective of groundwater quality

- Assess need and potential value of developing waste site-specific models.

Intermediate-term (FY-13 to 15): The foam process model will be applied and added to the ASCEM toolset to evaluate remediation design. The DVZ-AFRC will collaborate with ASCEM to incorporate a geophysics inversion capability into ASCEM so detailed vadose zone models can take advantage of 
geophysical surveys of the subsurface. Inverting geophysical data will be critical for parameterizing detailed models of the DVZ. Integration with the ASCEM DVZ working group will continue for demonstrating new capabilities. Predictive models will be applied to facilitate remediation design and to reduce the time for developing and implementing new approaches in the field.

Deliverables will support the 200-DV-1 and WMA C fate and transport model remedy evaluation:

- Applications of foam and other process models to evaluate remediation design

- Incorporation of the geophysics inversion capability into ASCEM

- Demonstration and application of new ASCEM capabilities to the DVZ-AFRC.

Long-term (FY-16 to 20): The DVZ-AFRC will apply detailed models to provide technical underpinnings for active and passive remediation approaches, including monitored natural attenuation and enhanced attenuation. The translational science and engineering simulation capabilities represented by ASCEM will be used to reduce development times for new remediation approaches as well as to optimize existing approaches.

Deliverables will support the design and implementation of remedies at 200-DV-1, WMA C and future tank farms:

- Application of ASCEM models to evaluate active and passive remediation approaches.

Collaborations: DVZ-AFRC predictive modeling activities will rely on collaborative relationships in place for several DOE EM-32 and DOE-SC sponsored projects, specifically ASCEM and SC scientific computing advances. ASCEM is a multi-laboratory effort between LBNL, PNNL, and Los Alamos National Laboratory as well as Oak Ridge National Laboratory, Savannah River National Laboratory, Lawrence Livermore National Laboratory, Idaho National Laboratory, and Argonne National Laboratory. The high-performance geophysical modeling and inversion codes developed under the Hanford 300 Area IFRC and LBNL will integrate with ASCEM to provide wider use and applicability throughout the DOEEM complex.

\subsubsection{National Deep Vadose Zone Program}

Many of the near-term (FY-11 to 12) results expected from the research and development (R\&D) program will move the state-of-the-art understanding and technologies for the DVZ into the state of practice. This means getting the current knowledge and capabilities already existing in the research communities into operational use at the nation's priority sites of vadose zone contamination. One benefit is that these tasks leverage other facets of the Hanford cleanup project and provide quick returns because much of the research investment has already been made. A less obvious benefit is that concerted effort to get new knowledge and technical capability into practice will bring researchers and solution-oriented problem owners into continuing and close interaction.

For the intermediate-term (FY-13 to 15), the outcomes of greatest significance are likely to be the cumulative advances in monitoring systems for vadose zone sites. A sound and efficient monitoring program is critical at major sites during and after environmental cleanup and throughout any period of stewardship required by residual contamination on site. The state of practice has been to monitor the 
groundwater at and around the site, rather than monitoring the vadose zone. However, for many sites where contaminants are at some distance from the water table, waiting until contaminants appear in the groundwater is less desirable than monitoring the vadose zone. If remediation can remove or isolate source terms and retain contaminants in the vadose zone, groundwater contamination can be prevented. In addition, the effectiveness of the remediation is often greatly enhanced, and the cost significantly reduced, compared with groundwater remediation alternatives.

Many of the long-term (FY-16 to 20) results will provide better tools for supporting site-wide assessments and decisions on environmental remediation and stewardship. The approach provided from ASCEM will enable an ability to visualize, quickly and accurately, the current and projected future states of site-wide vadose zone systems. These projections, which will carry levels of certainty and sensitivity unattainable at present, should suffice to gain the confidence of regulators and the public.

The national DVZ program area will transfer the framework for addressing DVZ challenges in characterization, monitoring, predictive simulation, and remediation that were built and exemplified at Hanford to other sites within the DOE Complex facing similar challenges, federal agencies, and local entities with responsibility for cleanup of contaminated sites, including regulatory agencies (EPA, various state regulatory agencies, etc.). This program area will provide better transfer and communication of the scientific basis of cleanup or stewardship decisions to stakeholders, those who are or could be affected by the consequences of vadose zone contamination, and by the decisions made by problem owners or regulators.

Near-term activities will focus on establishing the communication mechanisms and pathways to disseminate guidance advancing the understanding of vadose zone processes and properties in the context of remediation activities. This understanding provides the foundational framework to consider the risk and challenges for remediation of DVZ environments and the efficacy of technologies in achieving regulatory goals.

\section{Deliverables:}

- Develop mechanisms for scientific and public communities to engage, understand, and gain acceptance of DVZ remediation strategies.

Intermediate-term activities will focus on understanding DVZ issues throughout the DOE Complex and establishing the framework to transfer the knowledge and understanding gained by addressing DVZ remediation and closure issues at the Hanford Site to other sites. Additional activities will include providing a technical basis for conducting a monitored natural attenuation evaluation for DVZ contaminants.

\section{Deliverables:}

- National workshop for identifying and prioritizing sites, and associated issues, requiring vadose zone remediation

- Compilation of MNA/EA guidance and technical information for application to the DVZ.

Transferring the technical and regulatory knowledge gained through the DVZ-AFRC efforts at Hanford into operational use across the DOE Complex is critical to realizing the impact of the investment and addressing the nation's priority vadose zone site. These long-term activities will provide an improved 
approach to supporting site-wide assessments and decisions on environmental remediation of DVZ environments and stewardship.

Deliverables:

- Develop guidance document for DVZ remediation, closure, and transition decisions

- Compile DVZ remediation technology guidance and technical information. 


\subsection{DVZ-AFRC Management Plan}

The Management Plan covers the organizational structure for the DVZ-AFRC, including roles, responsibilities, operations, and partnerships with DOE Offices, site contractors, and others.

\subsection{DVZ-AFRC Organization Structure}

Figure 3.1 illustrates the organizational structure and current leadership for the DVZ-AFRC. This organization includes the DOE Management Team, the DVZ-AFRC Management and Integration Team, the DVZ-AFRC Steering Committee, and the DVZ-AFRC technical team comprising the four Research Areas.

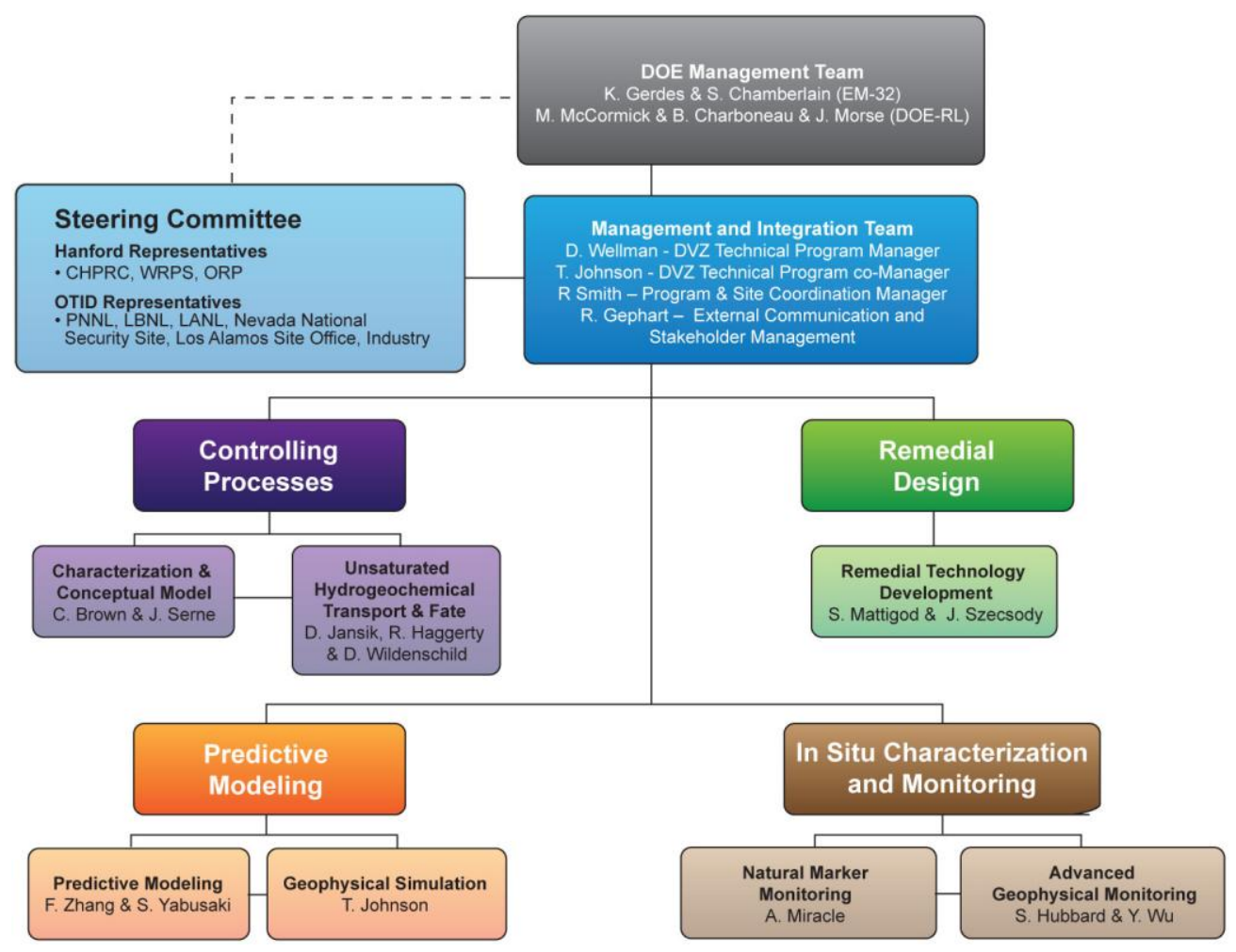

Figure 3.1. Organization Chart for the DVZ Applied Field Research Center

The DOE Office of Technology Innovation and Development (DOE-30) and DOE-RL initiated the DVZ-AFRC. The DVZ-AFRC provides the framework for coordinated and integrated research and technology development to produce the scientific and technical underpinning for new and innovative remedial strategies targeting the most challenging DVZ problems. This role leverages and is integrated with DOE Office of Science efforts, Hanford field investigations, and treatability testing done by the site contractors.

The management approach for the DVZ-AFRC requires close collaboration and communication between participants on the project, other EM-30 investigators, Office of Science, academia, industry, and field activities funded by DOE-RL, CH2M Hill Plateau Remediation Company (CHPRC), Washington River Protection Services (WRPS), and the Office of River Protection. For example, the DVZ-AFRC 
presently interfaces with the Hanford Site Soil and Groundwater Remediation Project (currently under the CHPRC Contract) for integration of treatability tests, drilling, and construction activities.

Several offices within DOE are involved in the DVZ-AFRC. The DOE Management Team includes DOE EM-32 and DOE-RL who provide funding for the project and oversight for conducting research. DOE-RL is also responsible for operation and remediation of the Central Plateau and therefore grants permission to operate in the Central Plateau and provides general project support and an interface to remediation activities underway.

The Steering Committee includes representatives from national laboratories, private industry, site contractors, and the basic sciences from within DOE, Office of Technology Innovation and Development (OTID), and ASCEM. It is responsible for reviewing and evaluating opportunities for enhancing investigations, laboratory research, and technology development efforts as well as efforts to integrate basic science and applied research into onsite activities to meet the DVZ characterization, remediation, modeling, and monitoring needs of DOE. The steering committee is also responsible for:

- Developing recommended resource allocation priorities to verify that the DVZ-AFRC efforts lead to tangible and field-deployable results

- Verifying DVZ-AFRC integration with DOE SC research, CHPRC treatability testing, and other laboratory to field related research activities supporting the characterization, modeling, monitoring, and remediation of the DVZ

- Providing guidance to make certain that a comprehensive understanding of the nature and extent of the contamination in the DVZ and appropriate remedial strategies are identified, developed, and demonstrated to mitigate subsurface contaminant migration and potential flux to groundwater

- Recommending resource allocation priorities and levels to DOE.

The Management and Integration Team is responsible for program operations, including project control, planning, research implementation, progress reporting, and communication. The Team will provide close collaboration between participants across the DVZ-AFRC and with other OTID investigators, SC researchers, industry, academia, and remediation activities underway by DOE contractors. The Management and Integration Team receives input from the DOE Management Team and the Steering Committee.

The key roles and responsibilities for staff that support the DVZ-AFRC are outlined in Table 3.1. 
Table 3.1. Summary of Key DVZ-AFRC Staff Roles and Responsibilities

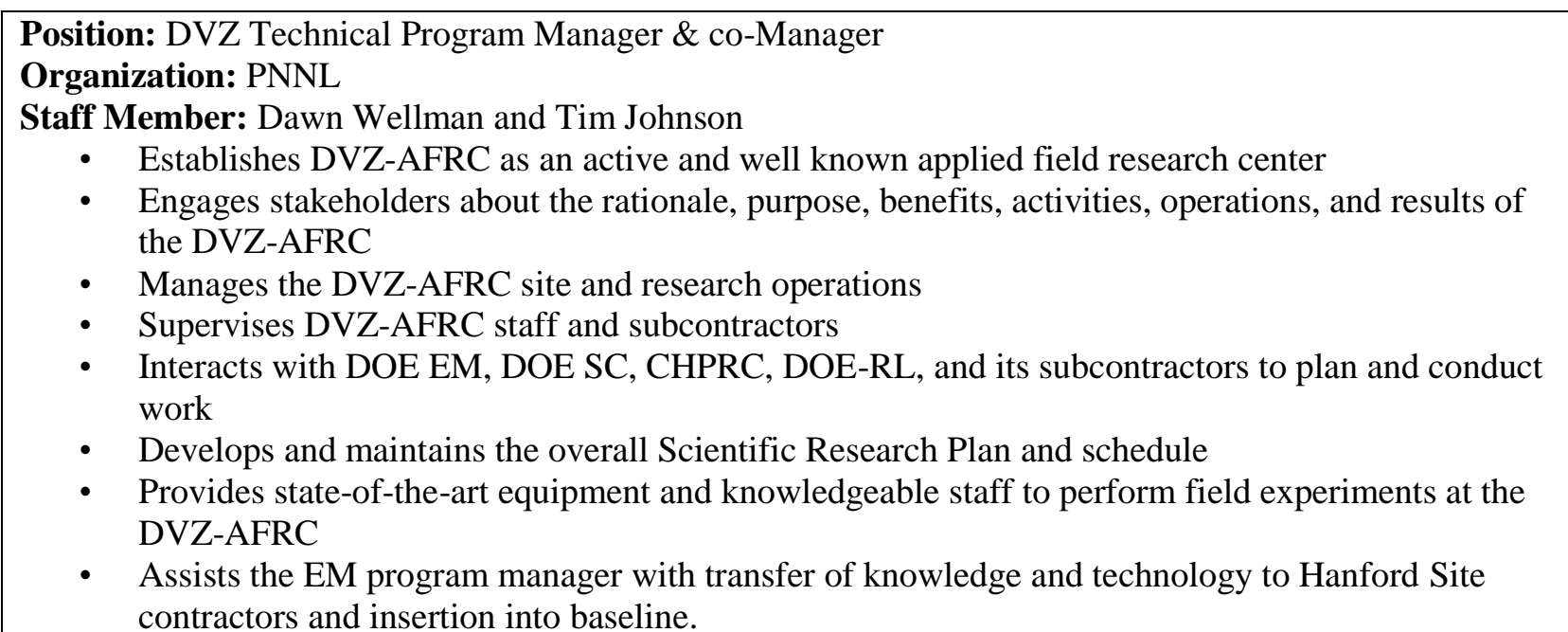

Position: Program and Site Coordination Manager

Organization: PNNL

Staff Member: Ron Smith

- Establishes and manages the DVZ-AFRC site operation procedures including permits, safety plans, training, and scheduling activities

- Supervises DVZ-AFRC staff and subcontractors during field operations

- Approves work plans for all field activities

- Oversees collection, tracking, and documentation of field samples

- Distributes groundwater and sediment materials to others.

Position: External Communications Management and Stakeholder Relations

Organization: PNNL

Staff Member: Roy Gephart

- Works with Technical Program manager and Co-manager to establish DVZ-AFRC as an active and well known applied field research center

- Facilitates communication among Hanford and external research community

- Engages stakeholders about the rationale, purpose, benefits, activities, operations, and results of the DVZ-AFRC

- Listens to stakeholders and incorporates their views into DVZ-AFRC plans, where appropriate.

Position: DVZ-AFRC Research Team Leaders

Organization: PNNL, LBNL, Oregon State University, MSE, and others

Staff Member: Various

- Participates in DVZ-AFRC research activities

- Reviews and follows all key plans and procedures

- Submits work plans for laboratory and field research, sampling, and analysis

- Provides technical progress reports

- First coordinates all external communication releases with management team.

Position: Office of Groundwater and Soil Remediation Office Director

Organization: DOE EM

Staff Member: Kurt Gerdes

- Works with EM program managers, DOE-RL, and PNNL to provide funding and support to the DVZ-AFRC

- Reviews DOE Technical Task Plan and Technical Fact Sheets for funding and provides budget

- Addresses the field-scale activities that are linked to the goals of the EM R\&D Plan through 1) 
Table 3.1. Summary of Key DVZ-AFRC Staff Roles and Responsibilities

\begin{tabular}{|c|c|}
\hline & $\begin{array}{l}\text { focused research efforts and 2) promoting development and testing of tools and strategies for } \\
\text { subsurface remediation } \\
\text { Promotes linkages and data dissemination among DOE programs and other federal agencies } \\
\text { Encourages synergism of investigations and operational activities between EM-30 centers. }\end{array}$ \\
\hline $\begin{array}{l}\text { Posi } \\
\text { Orge } \\
\text { Staff }\end{array}$ & $\begin{array}{l}\text { on: DOE Pacific Northwest Site Office (PNSO) } \\
\text { nization: PNSO } \\
\text { Member: TBD } \\
\text { Works with the EM program managers, PNSO, and PNNL to address funding and support } \\
\text { Works with EM program manager to address the DVZ-AFRC activities that are linked to the } \\
\text { goals of the EM R\&D Plan } \\
\text { Helps promote linkages and data dissemination among DOE programs and other federal agencies. }\end{array}$ \\
\hline $\begin{array}{l}\text { Posi } \\
\text { Orga } \\
\text { Staff }\end{array}$ & $\begin{array}{l}\text { on: DOE EM Richland Operations POC } \\
\text { nization: DOE Richland Operations } \\
\text { Member: John Morse } \\
\text { Coordinates with the EM program managers, PNSO, and PNNL to address support to the DVZ- } \\
\text { AFRC } \\
\text { Works with the DVZ Technical (co-)Program Manager(s) and Program and Site Coordination } \\
\text { Manager to maximize resources through coordinated sampling, characterization, and technology } \\
\text { development efforts } \\
\text { Works with EM program manager to address activities linked to the goals of the EM R\&D Plan } \\
\text { and DOE-RL. } \\
\text { Chairs the Steering Committee. }\end{array}$ \\
\hline $\begin{array}{r}\text { Orge } \\
\text { Staff } \\
\quad \cdot \\
\quad\end{array}$ & $\begin{array}{l}\text { nization: Regulatory Agencies } \\
\text { Member: Various staff at Environmental Protection Agency, Washington Department of Ecology } \\
\text { Provides regulatory oversight } \\
\text { Works with DOE-RL and the EM program manager to address the activities linked to the goals of } \\
\text { DOE-EM and Hanford Site cleanup. }\end{array}$ \\
\hline $\begin{array}{l}\text { Posi } \\
\text { Orga } \\
\text { Staff }\end{array}$ & $\begin{array}{l}\text { on: Plateau Remediation Contractor } \\
\text { nization: CH2M Hill Plateau Remediation Contract } \\
\text { Member: Marty Doornbos } \\
\text { Works with DOE-RL and the EM program manager to address activities that are integrated with } \\
\text { Hanford Site cleanup goals } \\
\text { Works with the DVZ Technical (co-)Program Manager(s) and Program and Site Coordination } \\
\text { Manager to maximize resources through coordinated sampling, characterization, and technology } \\
\text { development efforts } \\
\text { Provides drilling and well decommissioning services via subcontract. }\end{array}$ \\
\hline
\end{tabular}

As noted in Figure 3.1, four Research Teams report to the Management and Integration Team. Those teams are as follows: Controlling Processes, Predictive Modeling and Data Integration, Remedial Design, and In situ Characterization and Monitoring). Table 3.1 summarized leadership responsibilities for team leads.

\subsection{Program Requirements}

The success of the DVZ-AFRC requires that policy, institutional, and budget requirements be addressed as part of project planning and execution. Requirements described in this section include: 
- Coordination with site characterization, technology treatability testing, and scientific investigations to provide access to field test sites, data, and site materials for research and technology development

- Coordination and collaboration with site contractors and regulators to make sure that remediation contractors will use DVZ-AFRC products to meet regulatory requirements

- Assurance that project activities and deliverables can be completed in time to impact remediation and site closure decisions

- Potential need for additional field activities in support of Area Closure to test innovative technologies supporting characterization, remediation, modeling, and predictive simulation activities

- Need to maintain funding profiles for DVZ-AFRC and supporting EM initiatives (these funds need to be available at the start of each fiscal year to accomplish the program's goals in the aggressive time frames described in this implementation plan)

- Need to maintain expertise and resources necessary to address EM's long-term needs (i.e., field test facilities and information archives) to develop and use defensible conceptual understanding and site models to guide remediation actions and support DOE's long-term stewardship planning.

\subsection{Partnerships with Other DOE Offices, Site Contractors, and Organizations}

The DVZ-AFRC will leverage the efforts of and integrate with other Hanford Site DOE Offices and site contractor projects, DOE Complex-wide sites and contractor projects, plus DOE and U.S. Department of Defense (DOD) science and research innovation and technology initiatives. Projects covered that are part of or related to the DVZ Program include operable unit investigations for 200-WA-1, 200-EA-1, and 200-DV-1, the DVZ Treatability Test Plan, and groundwater operable unit remediation.

Figure 3.2 illustrates concepts associated with the maturation of basic research into deployment-ready engineering solutions.

DOE Richland Operations Office and contractor CH2M Hill Plateau Remediation Company (CHPRC): DOE-RL oversees Hanford Site projects associated with cleaning up the reactors, soil, groundwater, and solid waste burial sites. RL also manages the demolition of facilities and the disposition of the remaining plutonium left onsite. CHPRC is the prime contractor for the environmental cleanup of the Central Plateau at the Hanford Site. They are also responsible for waste retrieval and fuels management, groundwater and vadose zone remediation, demolition of facilities and canyons, and closure of the Plutonium Finishing Plant. Along the Columbia River, CHPRC is also remediating the 100K Area. A significant portion of the DVZ-AFRC work in the Central Plateau will be in collaboration with DOE-RL and CHPRC.

Key organizations involved in this development, transfer, and use of new research and innovative technologies include:

DOE Office of River Protection (ORP) and contractor Washington River Protection Solutions (WRPS): These two organizations address tank-farm closure and corrective action activities. Currently, this work focuses on WMA C located in the 200 East Area. Integration with these organizations will 


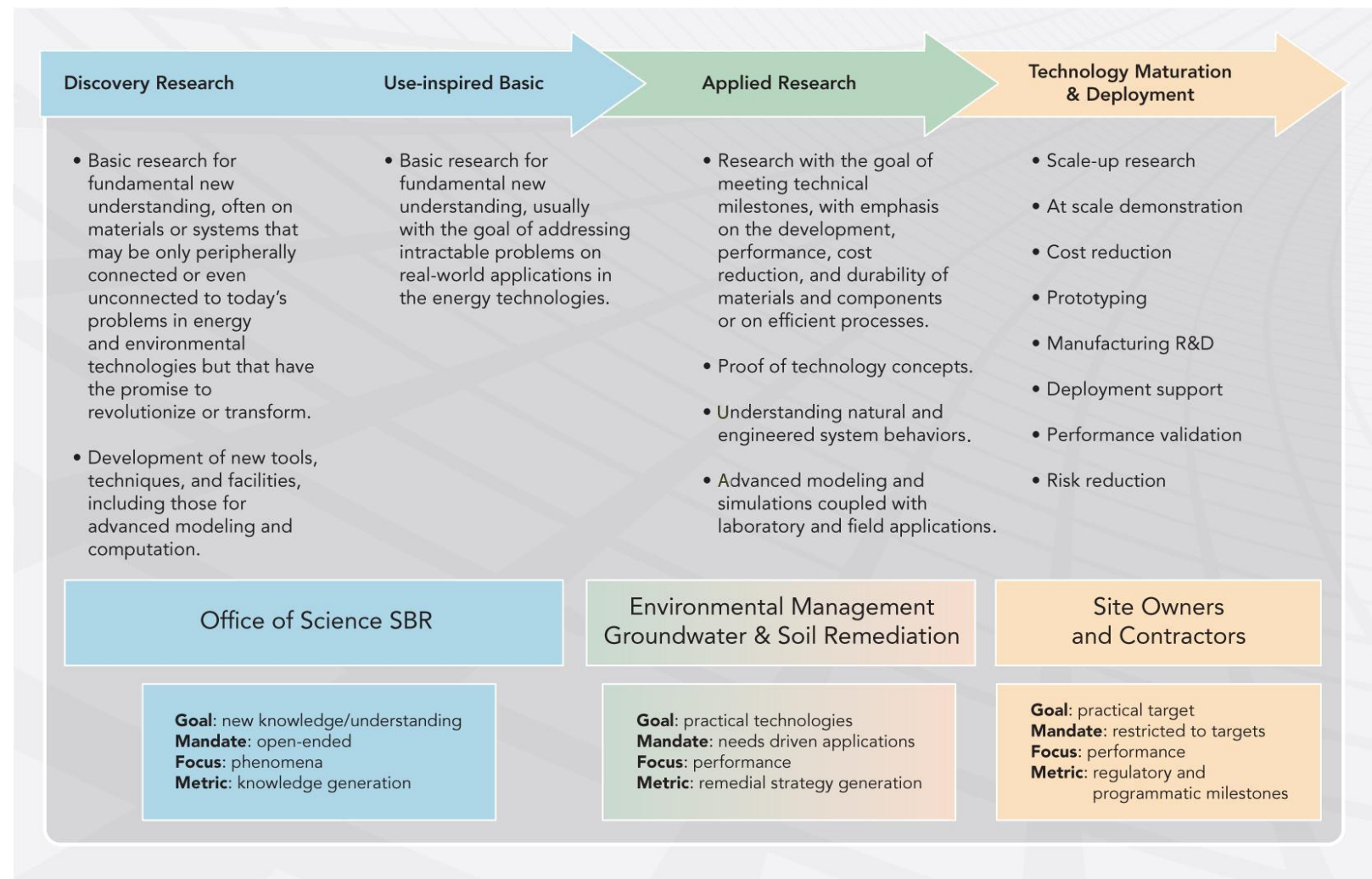

Figure 3.2. Linkage of Use-Inspired Basic Research and Applied Science to Support Technology Deployment

provide further opportunity to obtain site-specific materials from within and beneath the tank farms for scientific and technology development investigation to further advance our scientific and technical understanding of remedial technologies and controlling processes for source zones.

DOE EM-32 (Office of Groundwater and Soil Remediation within the DOE Office of Technology Innovation and Development): The success of the Groundwater and Soil Research and Development program requires multi-institutional and multi-disciplinary research teams composed of scientific specialists from several agencies - including national laboratories, universities, industry, and other federal and state agencies. Much of the work associated with this program is conducted within four integrated field research centers:

- Attenuation-Based Remedies for the Subsurface-Applied Field Research Center (Savannah River, South Carolina)

- Remediation of Mercury and Industrial Contaminants - Applied Field Research Center (Oak Ridge, Tennessee)

- Deep Vadose Zone-Applied Field Research Center (Hanford Site, Washington)

- Advanced Simulation Capability for Environmental Management (ASCEM) 
DOE Office of Science: Integration with the Subsurface Environmental System Sciences Program (SESP): The DVZ-AFRC will integrate with the SFA's lead by DOE-SC and advance information generated as part of SESP's integrated field research challenges to capitalize on the fundamental scientific understanding of coupled computational and experimental research. Physical/biological models as well as sediments and microbial consortia and isolates from multiple Hanford Site settings will be used. This will enable researchers to understand the role of microenvironments and transition zones in the reactive transport of technetium, uranium, and plutonium. In addition, the DVZ-AFRC is working with LBNL's Sustainable Systems SFA to explore how geophysical methods that can be used to track the evolution of pore structures and field-scale flowpaths associated with remediation-induced end-products, such as precipitates or gases.

Department of Defense: Integration with the DOD Strategic Environmental Research and Development Program and Environmental Security Technology Certification Program efforts in technology innovation for environmental remediation and monitoring provides synergy and leveraging of resources to develop technologies and scientific understanding for mutual benefits on common remediation goals being undertaken by DOE and DOD.

Pacific Northwest National Laboratory: PNNL is responsible for the management and integration functions of the DVZ-AFRC. This includes making certain that the coordinated and integrated research and technology development produces the scientific and capability underpinnings required for new and innovative remedial strategies target DVZ problems.

\subsection{Communication and External Outreach}

The DVZ-AFRC will maintain a timely, open, and transparent dialogue with the regulators, public, Native Tribes, and other interested stakeholders about DVZ activities, findings, and plans. This engagement will be coordinated through DOE.

Outreach will be as tailored to the needs of audiences and as informal as possible to expedite the distribution of key information. More formal communication will be provided as needed.

A communication plan will be developed to support the DVZ-AFRC. The primary objectives of that plan will be to:

- Meet external communication needs

- Support DOE's external public involvement process

- Solicit input from the public and others about the information they need to remain informed

- Develop presentations, briefings, fact sheets, and other forms of written, oral, or electronic information sources to provide audiences with a clear, accurate, and complete understanding of subsurface contamination challenges faced, project scope, and accomplishments

- Create and promote Web-based products and communication approaches

- Address critical documents and other information products requiring review so they are made available in a timely manner through DOE-RL 
- Coordinate all interactions with the news media through DOE-RL media relations point of contact. Information will be shared through press releases, interviews, and other appropriate venues

- Create an awareness for and interest about the DVZ-AFRC project and activities.

Examples of meetings where external communication about the DVZ-AFRC activities would take place include those with the Deep Vadose Zone Multi-Project Team, Hanford Advisory Board, Oregon Hanford Cleanup Board, Hanford Communities, and Hanford Natural Resources Trustee Council. 


\subsection{DVZ-AFRC Execution Plan}

Section 4.0 describes what the DVZ-AFRC will deliver, when, at what costs, and how progress will be measured and tracked.

\subsection{DVZ Implementation Schedule}

Figure 4.1 and Figure 4.2 show the principal activities and milestones for Hanford's end user projects (tank farm and non-tank-farm sites), DVZ treatability testing, DVZ-AFRC, and DOE SC-funded activities. This implementation schedule begins with the near-term (Figure 4.1) and continues through the intermediate-and long-term (Figure 4.2).

In general, near-term (FY-11 to 12) deliverables support the earlier stages of remedial investigations (and RCRA facility investigations) including technology screening, baseline risk assessment, remedial investigation, and assessment of interim actions. Intermediate term (FY-13 to 15) deliverables generally support the definition and evaluation of possible remedial actions in CERCLA feasibility studies and RCRA corrective measures studies. Long-term (FY-16 to 20) deliverables focus more on design and implementation of final remedies and corrective measures including long-term monitoring methods. 


\section{Deep Vadose Zone Near-Term Implementation Schedule}

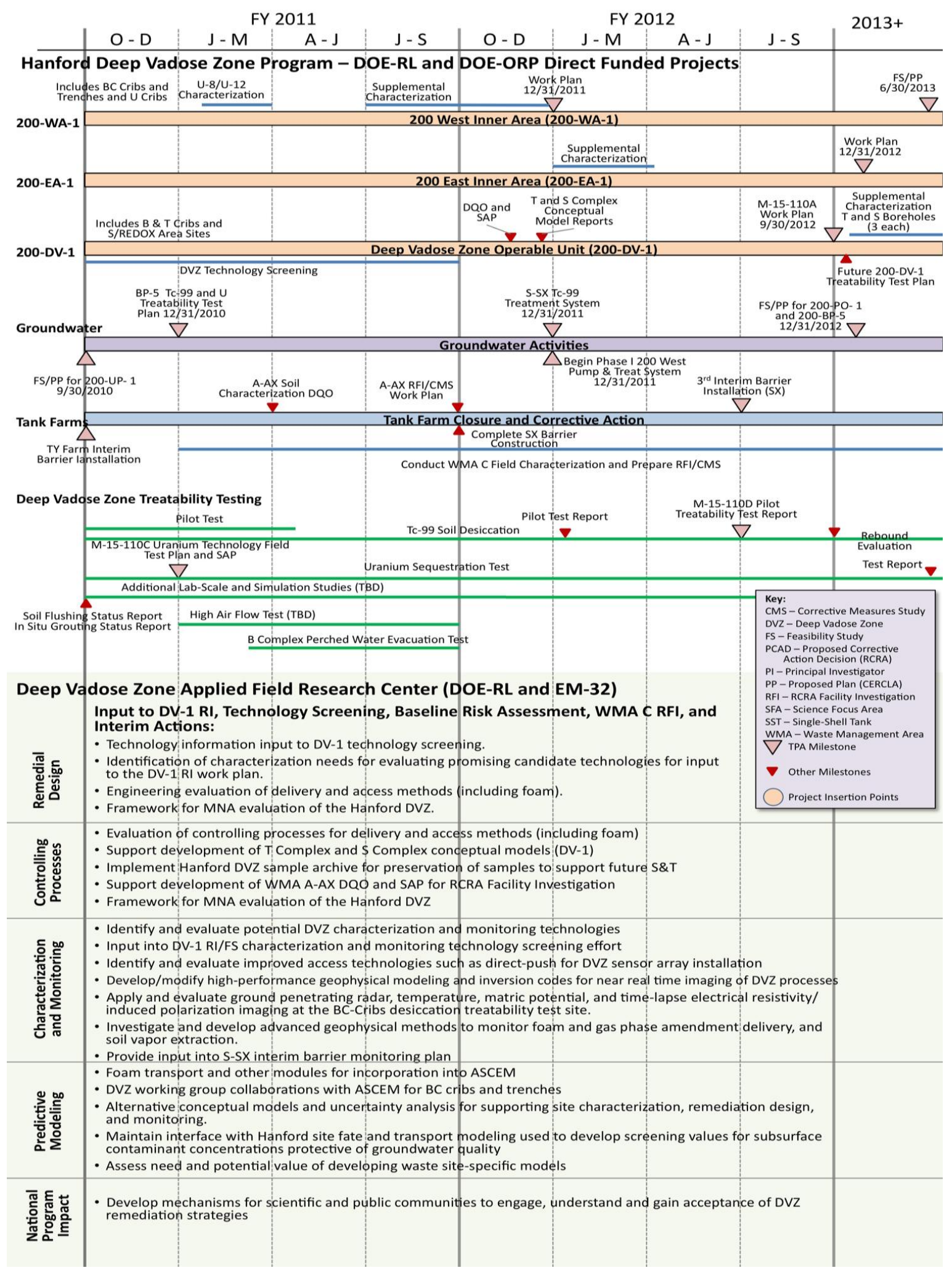

Figure 4.1. Near-Term DVZ Implementation Schedule 


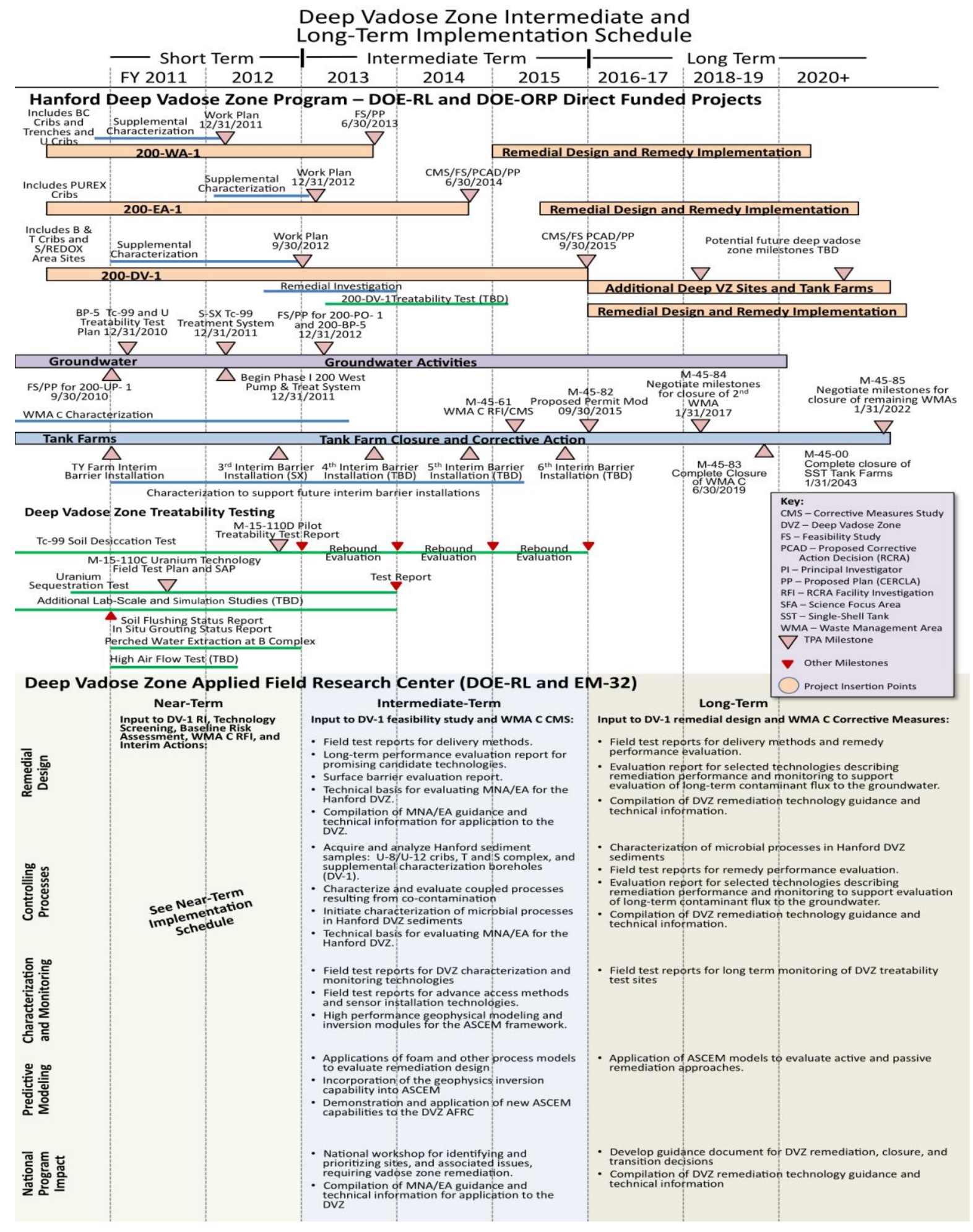

Figure 4.2. Intermediate-to Long-Term DVZ Implementation Schedule 


\subsection{Budget}

This section identifies specific near-term to long-term budgets for the DVZ-AFRC research deliverables within the programmatic areas of remedial design, controlling processes, in situ characterization and monitoring, and predictive modeling and data integration. Budgets are linked to the proposed integrated goals and deliverables noted in Section 2.0.

A cornerstone to DOE's DVZ remediation strategy centers upon balancing resource investments solving both near-term capability needs and long-term research challenges directed at regulatory compliance, cleanup, and waste site closure. Balancing these competing drivers will sustain both "bias for action" and "scientific sufficiency" priorities for program implementation. The DVZ-AFRC strongly leverages other budgeted activities by DOE SC through the PNNL and LBNL SFAs, the PNNL IFRC, other EM Field Research Centers, ASCEM, and Site-funded remediation activities.

The proposed DVZ-AFRC budgets covering the near-term (FY-11 to FY-12), intermediate-term (FY13 to FY-15), and long-term (FY16 to FY-20) are found in Table 4.1. Budget estimates for DOE-RL work scope for FY-13 to 20 are under development and not available at the time this implementation Plan was published. Also, RL and ORP estimates for FY-11 and FY-12 are subject to change in accordance with Congressional budget guidance that is forthcoming.

\subsection{Project Performance Metrics and Monitoring}

The mechanism to track and report progress will be the monthly earned-value management system (EVMS) report. In this report, the DVZ-AFRC Technical Program Manager, Program and Site Operations Manager, and the four Research Leads have the responsibility to document monthly cost and schedule progress as well as identify and develop mitigation plans for any identified programmatic risks.

Through the Monthly EVMS report, the DVZ-AFRC Technical Program Manager reports these plans to DOE-EM and -RL for their concurrence. If the risk mitigation strategy appears ineffective, the Technical Program Manager and Research Leads will discuss options and engage DOE-EM, -RL and the Steering Committee on approaches to reduce programmatic or technical risks.

In addition to the standard EVMS tools to monitor progress of the DVZ-AFRC program, project technical direction will be monitored through peer review via the Steering Committee. Peer reviews of Federal technical programs have recognized value within government agencies. The Steering Committee will review key planning documents and deliverables. Review findings and recommendations will be used to address the creation of high-quality, targeted products and improve end-user acceptance. Upon DOE request, the DVZ-AFRC Management and Integration Team will provide technical support to these reviews. 
Table 4.1. DVZ Budget Summary

\begin{tabular}{|c|c|c|c|c|c|}
\hline \multirow{2}{*}{ Activity } & \multicolumn{2}{|c|}{ Near-Term } & \multirow{2}{*}{$\begin{array}{c}\begin{array}{c}\text { Intermediate- } \\
\text { Term }\end{array} \\
\text { FY-13-15 \$K }\end{array}$} & \multirow{2}{*}{$\begin{array}{c}\text { Long-Term } \\
\text { FY-16-20 \$K }\end{array}$} & \multirow{2}{*}{ Work Scope Description } \\
\hline & FY-11 \$K & FY-12 \$K & & & \\
\hline $\begin{array}{l}\text { Deep Vadose Zone Applied } \\
\text { Field Research Center } \\
\text { (excludes DOE-OS } \\
\text { funding }\end{array}$ & $\$ 3,000$ & $\$ 5,000$ & $\$ 6,000 / \mathrm{yr}$ & $\$ 5,000 / \mathrm{yr}$ & \\
\hline Remedial Design & $\$ 1,000$ & $\$ 1,500$ & \begin{tabular}{|l} 
- $\begin{array}{l}\$ 750 / y r \\
\text { work \& }\end{array}$ \\
data/technology \\
analysis \\
- $\$ 1,250 / y r$ field \\
test operations \\
- $\$ 1,000 / y r$ field \\
test site \\
infrastructure \\
(shared with \\
other program \\
areas and site \\
contractors)
\end{tabular} & $\begin{array}{l}\text { - } \$ 500 / \mathrm{yr} \text { for } \\
\text { data and } \\
\text { technology } \\
\text { analysis } \\
\text { - } \$ 1,000 / \mathrm{yr} \\
\text { field test } \\
\text { operations }\end{array}$ & $\begin{array}{l}\text { Perform applied research to broaden the suite } \\
\text { of remedies available for DVZ contamination } \\
\text { and enhance the technical basis for } \\
\text { evaluating DVZ remedy effectiveness, } \\
\text { implementability, and cost. } \\
\text { Elements of the scope include: } \\
\text { - Innovative technology screening } \\
\text { - Applied remediation development } \\
\text { - Advanced amendment delivery } \\
\text { - Long-term effectiveness of potential } \\
\text { remedies. }\end{array}$ \\
\hline
\end{tabular}


Table 4.1. DVZ Budget Summary

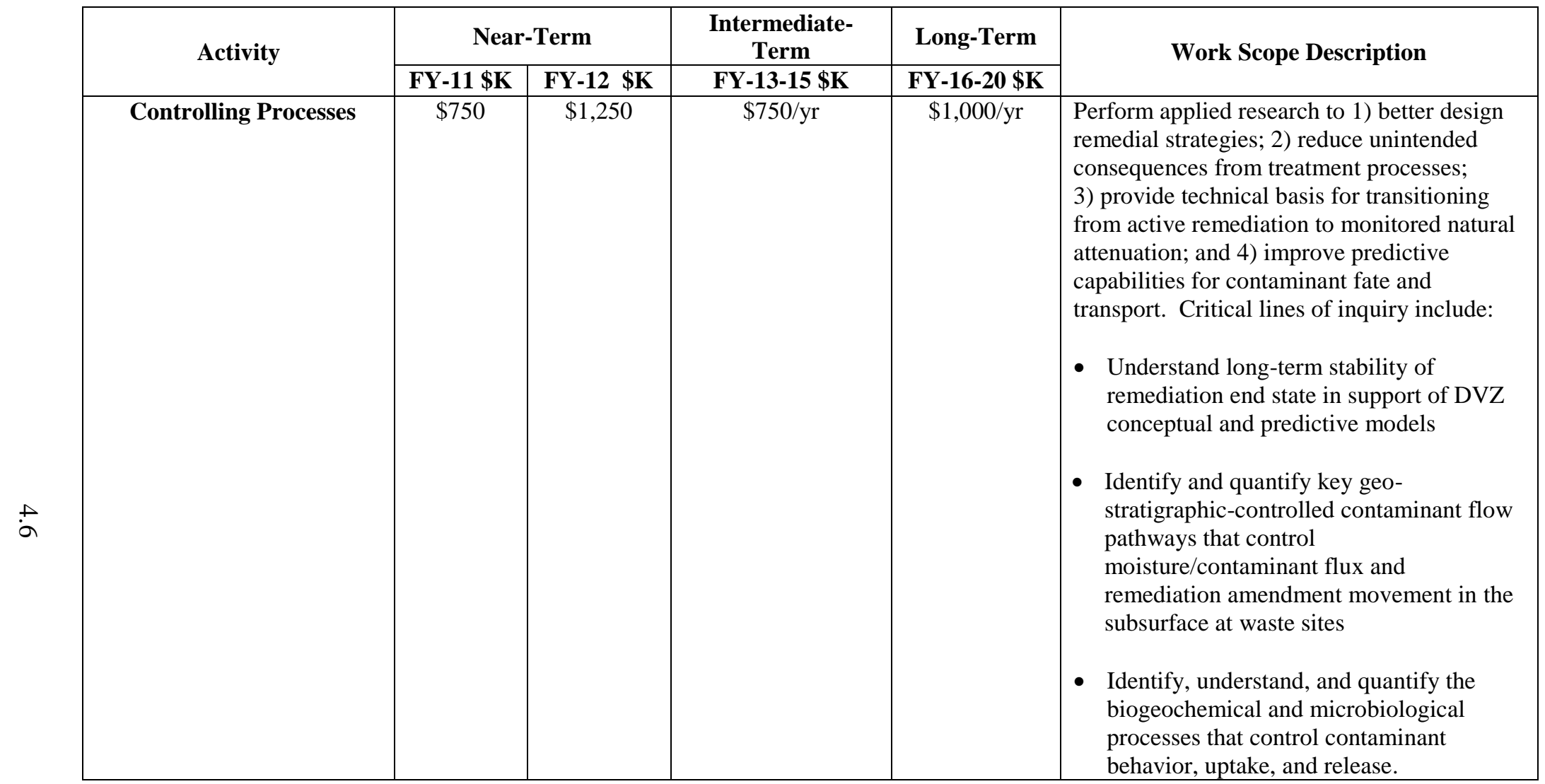


Table 4.1. DVZ Budget Summary

\begin{tabular}{|c|c|c|c|c|c|}
\hline \multirow{2}{*}{ Activity } & \multicolumn{2}{|c|}{ Near-Term } & \multirow{2}{*}{$\begin{array}{c}\begin{array}{c}\text { Intermediate- } \\
\text { Term }\end{array} \\
\text { FY-13-15 \$K } \\
\end{array}$} & \multirow{2}{*}{$\begin{array}{c}\text { Long-Term } \\
\text { FY-16-20 \$K }\end{array}$} & \multirow{2}{*}{ Work Scope Description } \\
\hline & FY-11 \$K & FY-12 \$K & & & \\
\hline $\begin{array}{l}\text { In Situ } \\
\text { Characterization and } \\
\text { Monitoring }\end{array}$ & $\$ 500$ & $\$ 1,000$ & $\$ 1,000 / \mathrm{yr}$ & $\$ 1,000 / \mathrm{yr}$ & $\begin{array}{l}\text { Perform applied research to develop } \\
\text { characterization and monitoring technologies } \\
\text { for in situ characterization of DVZ } \\
\text { geochemical and hydrologic properties } \\
\text { controlling contaminant transport, and } \\
\text { monitor DVZ processes, contaminant } \\
\text { movement, and remediation performance. } \\
\text { Critical lines of inquiry include: } \\
\text { - Access and Characterization techniques } \\
\text { - Remediation monitoring techniques } \\
\text { - Early warning thresholds of unexpected } \\
\text { behavior }\end{array}$ \\
\hline $\begin{array}{l}\text { Predictive Modeling } \\
\text { and Data Integration }\end{array}$ & $\$ 250$ & $\$ 500$ & $\$ 500 / y r$ & $\$ 500 / \mathrm{yr}$ & $\begin{array}{l}\text { Provide scientific and technology } \\
\text { information to support CERCLA fate and } \\
\text { transport assessments of long-term } \\
\text { performance for remedial alternatives and } \\
\text { reduce remedial design development and } \\
\text { implementation times by applying simulation } \\
\text { capabilities. Critical lines of inquiry include: } \\
\\
\text { - Develop calibrated models to predict the } \\
\text { mobility of risk-driving contaminants and } \\
\text { their reactive transport for the range of } \\
\text { waste, geochemical, and hydrological } \\
\text { conditions prominent to DVZ natural } \\
\text { attenuation or engineered remediation. } \\
\text { This line of inquiry will be addressed } \\
\text { through collaboration with ASCEM } \\
\text { - Facilitate development and utilization of } \\
\text { remediation technology performance } \\
\text { modeling to support Feasibility Studies. }\end{array}$ \\
\hline
\end{tabular}


Table 4.1. DVZ Budget Summary

\begin{tabular}{|c|c|c|c|c|c|}
\hline \multirow{2}{*}{ Activity } & \multicolumn{2}{|c|}{ Near-Term } & \multirow{2}{*}{$\begin{array}{c}\text { Intermediate- } \\
\text { Term }\end{array}$} & \multirow{2}{*}{$\begin{array}{c}\text { Long-Term } \\
\text { FY-16-20 \$K }\end{array}$} & \multirow[t]{2}{*}{ Work Scope Description } \\
\hline & FY-11 \$K & FY-12 \$K & & & \\
\hline $\begin{array}{l}\text { National Deep Vadose } \\
\text { Zone Program }\end{array}$ & $\$ 500$ & $\$ 750$ & $\$ 750 / \mathrm{yr}$ & $\$ 1,000 / \mathrm{yr}$ & $\begin{array}{l}\text { Transfer the framework for addressing DVZ } \\
\text { challenges in characterization, monitoring, } \\
\text { predictive simulation, and remediation that } \\
\text { were built and exemplified at Hanford to } \\
\text { other sites within the DOE Complex facing } \\
\text { similar challenges, federal agencies, and local } \\
\text { entities with responsibility for cleanup of } \\
\text { contaminated sites, including regulatory } \\
\text { agencies (EPA, various state regulatory } \\
\text { agencies, etc.). Critical activities to achieve } \\
\text { this include: } \\
\text { - Scientific and public acceptance of DVZ } \\
\text { remediation strategies } \\
\text { - Compilation of DVZ remediation } \\
\text { technology, closure, and transition } \\
\text { decisions guidance } \\
\text { - State of Practice for Understanding and } \\
\text { Technologies. }\end{array}$ \\
\hline $\begin{array}{l}\text { Office of Science - Science } \\
\text { Focus Area Funding }\end{array}$ & $\$ 300$ & $\$ 300$ & $\$ 500 / \mathrm{yr}$ & $\$ 500 / \mathrm{yr}$ & $\begin{array}{l}\text { Work scope includes: } \\
\text { - SFA-focused analyses of samples for U } \\
\text { Cribs to support improved understanding } \\
\text { of uranium mobility and to support U } \\
\text { sequestration treatability testing } \\
\text { - Evaluation of geophysical feedback } \\
\text { resulting from remediation-induced } \\
\text { biogeochemical transformations and flow } \\
\text { characteristics at the field scale } \\
\end{array}$ \\
\hline $\begin{array}{l}\text { DOE-RL and ORP Direct- } \\
\text { Funded Projects }\end{array}$ & & & & & \\
\hline
\end{tabular}


Table 4.1. DVZ Budget Summary

\begin{tabular}{|c|c|c|c|c|c|}
\hline \multirow{2}{*}{ Activity } & \multicolumn{2}{|c|}{ Near-Term } & \multirow{2}{*}{$\begin{array}{c}\begin{array}{c}\text { Intermediate- } \\
\text { Term }\end{array} \\
\text { FY-13-15 \$K } \\
\end{array}$} & \multirow{2}{*}{$\begin{array}{c}\text { Long-Term } \\
\text { FY-16-20 \$K }\end{array}$} & \multirow{2}{*}{ Work Scope Description } \\
\hline & FY-11 \$K & FY-12 \$K & & & \\
\hline $\begin{array}{l}\text { Direct Operable Unit } \\
\text { Work Scope }\end{array}$ & $\$ 10,860$ & $\$ 12,840$ & $\$ \mathrm{TBD} / \mathrm{yr}$ & $\$ \mathrm{TBD} / \mathrm{yr}$ & $\begin{array}{l}\text { - Conduct 200-DV-1 Operable Unit } \\
\text { investigation, remedy selection, and } \\
\text { remedy implementation } \\
\text { - Conduct site investigation, remedy } \\
\text { selection, and remedy implementation for } \\
\text { other Operable Unit work involving DVZ } \\
\text { sites (e.g., BC cribs and trenches, U } \\
\text { cribs). } \\
\end{array}$ \\
\hline $\begin{array}{l}\text { Deep Vadose Zone } \\
\text { Treatability Testing }\end{array}$ & $\$ 7,000$ & $\$ 2,140$ & $\$ T B D / y r$ & $\$ \mathrm{TBD} / \mathrm{yr}$ & $\begin{array}{l}\text { Conduct treatability tests for: } \\
\text { - } \quad{ }^{99} \text { Tc Desiccation Pilot Test } \\
\text { - Uranium Sequestration Test } \\
\text { - } \quad \text { Laboratory studies (barrier performance, } \\
\text { - } \quad \text { oil flushing, in situ grouting, etc) } \\
\text { - } \quad \text { Herched Water Extraction at B Complex } \\
\quad \text { Test } \\
\text { Perfocity, Pore-Water Extraction } \\
\text { Treatability Testing. }\end{array}$ \\
\hline $\begin{array}{l}\text { Tank Farm Vadose Zone } \\
\text { Interim Actions and } \\
\text { Technology Development, } \\
\text { Characterization, and } \\
\text { Corrective Action }\end{array}$ & $\$ 11,600$ & $\$ 14,200$ & $\$ 9,100 / \mathrm{yr}$ & $\$ 7,300 / \mathrm{yr}$ & $\begin{array}{l}\text { - Deploy interim barriers and other interim } \\
\text { actions. } \\
\text { - Develop enhanced characterization } \\
\text { methods. } \\
\text { - Conduct soil characterization and } \\
\text { monitoring. } \\
\text { - Conduct past leak assessments. } \\
\text { - Prepare RFI/CMS for WMA C. } \\
\text { - Prepare WMA C Performance } \\
\text { Assessment. }\end{array}$ \\
\hline
\end{tabular}




\subsection{References}

Dean DJ. 2010. Computational Science and Innovation. White Paper. Oak Ridge National Laboratory, Oak Ridge, Tennessee.

DOE-RL_U.S. Department of Energy-Richland Operations Office. 2008. Deep Vadose Zone Treatability Test Plan for the Hanford Central Plateau. DOE/RL-2007-56, Rev. 0, Richland, Washington.

DOE-RL_U.S Department of Energy, Richland Operations Office. 2010. Long-Range Deep Vadose Zone Program Plan. DOE/RL-2010-89. Rev 0, Richland, Washington.

Koonin SE. March 18, 2010. Statement of Dr. Steven Koonin, Under Secretary for Science, U.S. Department of Energy before the Subcommittee on Energy and Water Development, Committee on Appropriations, U.S. House of Representatives, FY2011 Appropriations Hearing. Washington D.C.

NRC — National Research Council. 2000. Research Needs in Subsurface Science. National Academy Press, Washington, D.C.

NRC - National Research Council. 2001. Science and Technology for Environmental Cleanup at Hanford. National Academy Press, Washington, D.C.

NRC — National Research Council. 2009. Advice on the Department of Energy's Cleanup Technology Roadmap: Gaps and Bridges. The National Academy Press, Washington, D.C. 


\section{Appendix A}

\section{Deep Vadose Zone Problem Areas and Short Descriptions}




\section{Appendix A: Deep Vadose Zone Problem Areas and Short Descriptions}

This appendix contains waste site summary descriptions for the major DVZ problem areas contained within the Inner Area of the Hanford Site. These descriptions include an overview of the contamination challenge, status of current problem-focused activities, and a depiction of the remediation schedule these activities support. Use Figure A.1 to locate each DVZ remediation challenge ${ }^{1}$.

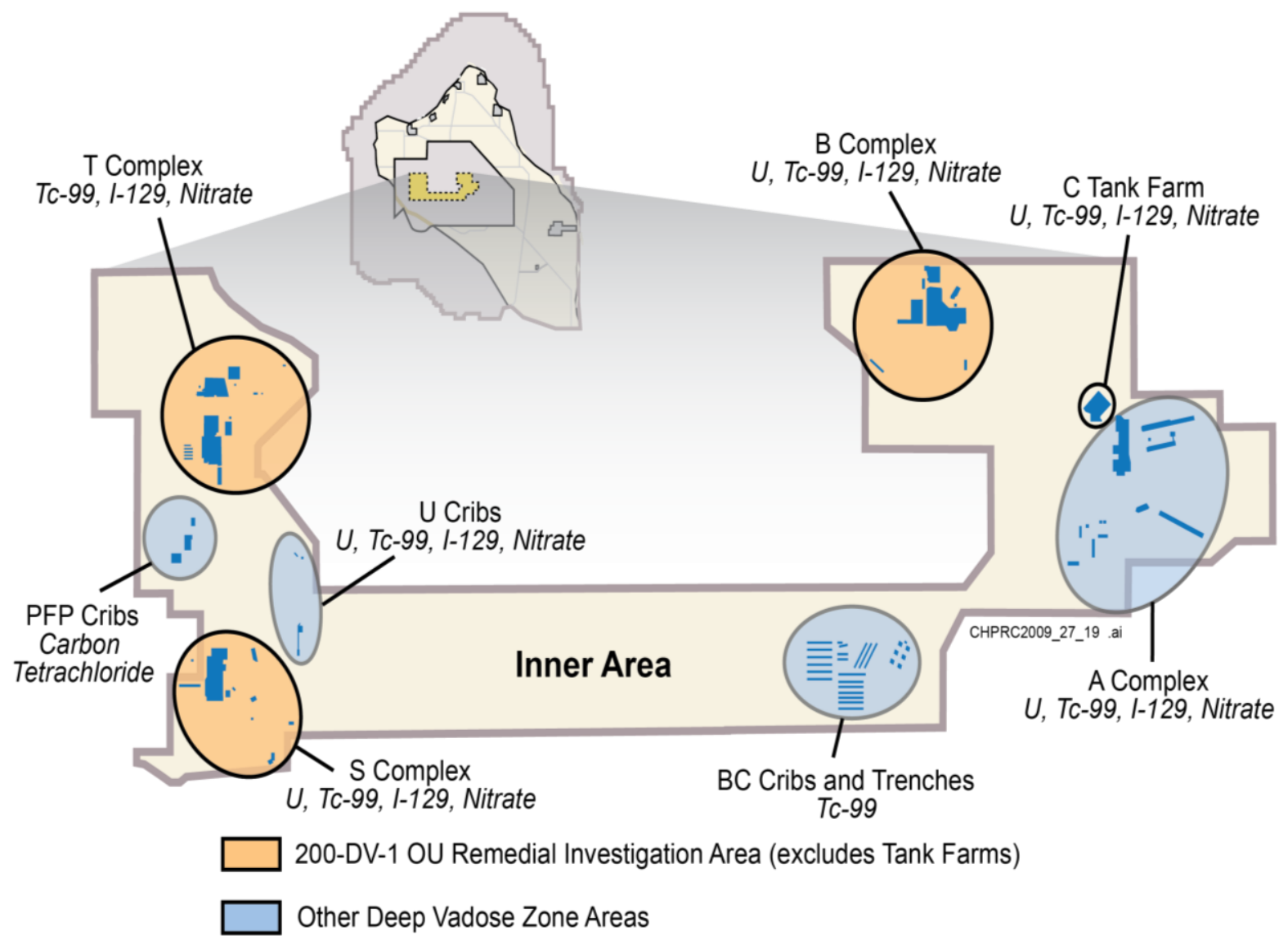

$8 \mathrm{~km}(5 \mathrm{mi})$

Figure A.1. DVZ Problem Areas and Descriptions

\footnotetext{
${ }^{1}$ Figure A.1 also shows the deep vadose zone carbon tetrachloride contaminant area associated with past operations of the Plutonium Finishing Plant (PFP). Appendix A does not provide a separate summary of this area because an active soil vapor extraction system has been in place since the mid-1990s. This system along with an expanded groundwater pump-and-treat system is expected to be sufficient to meet remediation goals. Enhanced DVZ remediation methods are not expected to be required for this area.
} 
Acronyms commonly used in this appendix include the following:

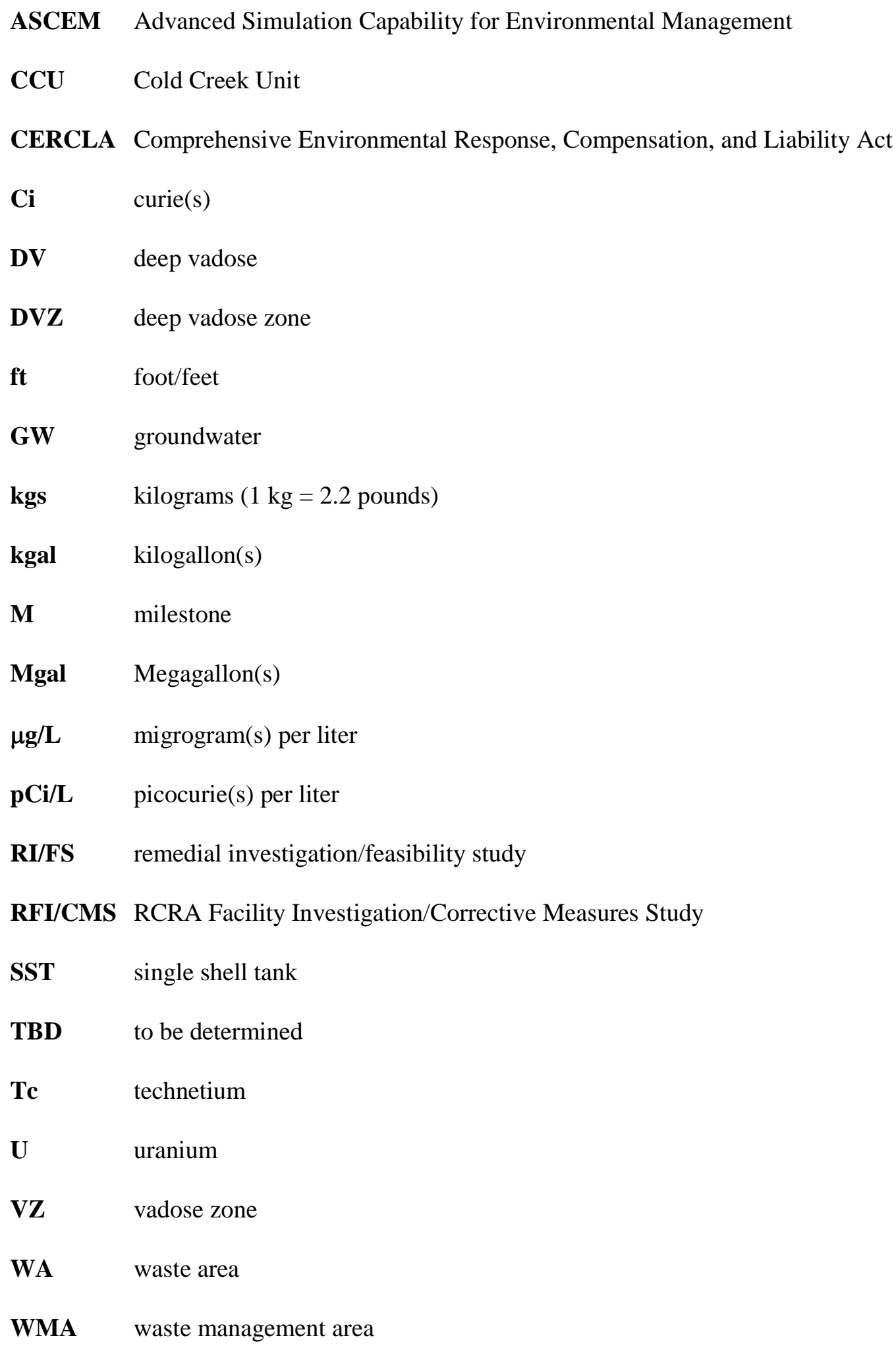




\section{Deep Vadose Zone Challenge: BC Cribs and Trenches}

\begin{tabular}{|c|c|c|}
\hline Nature of the Problem & & Current Activities \\
\hline $\begin{array}{l}\text { Site Description: } 35 \text { acre site with } 26 \text { cribs and } \\
\text { trenches that received } \sim 30 \text { million gallons of } \\
\text { liquid waste cascaded from tank farms from } \\
1956 \text { to } 1965 \text {. Inventory includes } \sim 410 \mathrm{Ci} \text { of } \\
{ }^{99} \mathrm{Tc} \text {, more than } 1 / 2 \text { of the total soil inventory of } \\
\text { ter is } \sim 300 \mathrm{ft} \text {. }\end{array}$ & $\begin{array}{l}\text { Controlling } \\
\text { Processes }\end{array}$ & $\begin{array}{l}\text { - Fundamental science investigations of the redox } \\
\text { state and Tc reactivity in a variety of Hanford } \\
\text { vadose and saturated zone sediments. } \\
\text { - Investigate redox chemistry of }{ }^{99} \mathrm{Tc} \text { in } 200 \text { Area } \\
\text { sediments. } \\
\text { - Characterize intragrain microscopic transport } \\
\text { processes of U and }{ }^{99} \mathrm{Tc} \text { in different Hanford } \\
\text { sediment facies. } \\
\text { - Characterize geochemical and hydrodynamic } \\
\text { features of BC Cribs field site. }\end{array}$ \\
\hline \multirow{2}{*}{$\begin{array}{l}\text { Nature of the DVZ Threat: }{ }^{99} \mathrm{Tc} \text { inventory is } \\
\text { highly mobile }\left(\mathrm{K}_{\mathrm{d}}=0\right) \text { in the subsurface. Extent } \\
\text { of VZ plume is predominantly } 100 \text { to } 150 \mathrm{ft} \\
\text { below ground level with extensive lateral } \\
\text { spreading due to the presence of multiple thin, } \\
\text { fine-grained silt lenses in the subsurface. No } \\
\text { breakthrough to GW has been detected to date, } \\
\text { but transport model predictions indicate the } \\
\text { potential for future adverse impacts to GW } \\
\text { if remedial actions are not successful. }\end{array}$} & $\begin{array}{c}\text { Predictive } \\
\text { Modeling and } \\
\text { Data Integration }\end{array}$ & $\begin{array}{l}\text { - Develop reactive transport behavior models. } \\
\text { - Perform modeling of soil desiccation system. } \\
\text { - Develop numerical model to simulate foam trans- } \\
\text { port, remedial delivery, and implementation. } \\
\text { - Develop and apply ASCEM modeling capability } \\
\text { to BC Cribs field site. }\end{array}$ \\
\hline & Remedial Design & $\begin{array}{l}\text { - Conduct pilot-scale treatability test for soil } \\
\text { desiccation. } \\
\text { - Conduct treatability test for pore water extraction. } \\
\text { - Evaluate the efficacy of foam-based delivery of } \\
\text { remedial amendments. } \\
\text { - Evaluate long-term performance of surface } \\
\text { barriers. }\end{array}$ \\
\hline $\begin{array}{l}\text { Current Status: Undergoing CERCLA RI/FS as } \\
\text { part of the } 200 \text {-WA-1 operable unit (see schedule). } \\
\text { Field treatability testing for soil desiccation and } \\
\text { pore water extraction is ongoing. }\end{array}$ & $\begin{array}{l}\text { In Situ } \\
\text { Characterization } \\
\text { and Monitoring }\end{array}$ & $\begin{array}{l}\text { - Monitor site through routine environmental } \\
\text { sampling. } \\
\text { - Monitor progress/impact of the desiccation test. }\end{array}$ \\
\hline
\end{tabular}

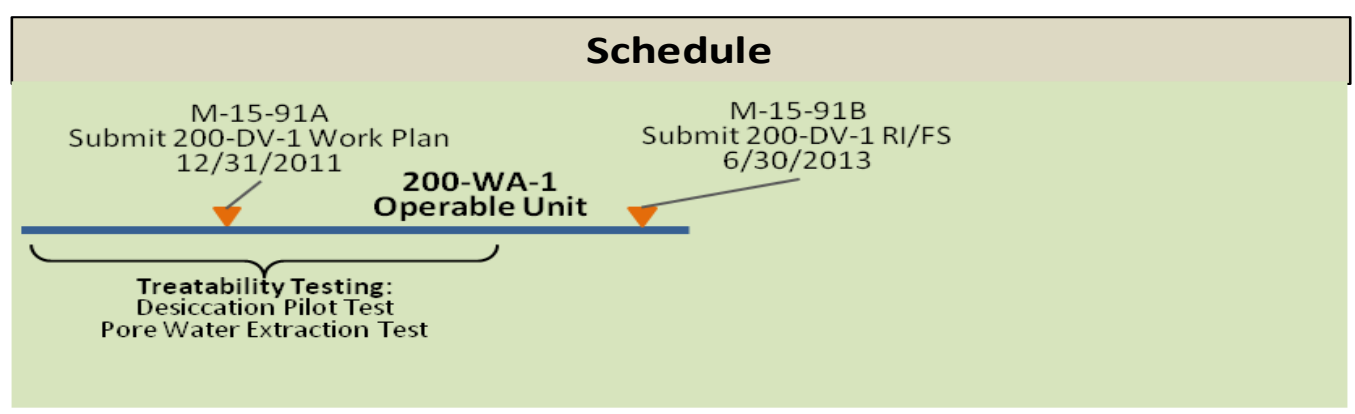




\section{Deep Vadose Zone Challenge: B Complex Uranium}

\begin{tabular}{|c|c|c|}
\hline Nature of the Problem & & Current Activities \\
\hline $\begin{array}{l}\text { Site Description: Single shell tank (SST) over- } \\
\text { fill event in } 1951 \text { released about } 70 \text { to } 90 \mathrm{kgal} \\
\text { containing } \sim 10,000 \mathrm{kgs} \text { of uranium. Lateral } \\
\text { migration } \sim 300 \mathrm{ft} \text { outside of BX tank farm. } \\
\text { Depth to GW } \sim 270 \mathrm{ft} \text {. Commingled U and }{ }^{99} \mathrm{Tc} \\
\text { plumes from other sources, including } 200-\mathrm{DV}-1 \\
\text { operable unit waste sites. Extensive perched } \\
\text { water zone just above aquifer contains signifi- } \\
\text { cant inventory of mobile uranium. }\end{array}$ & $\begin{array}{c}\text { Controlling } \\
\text { Processes }\end{array}$ & $\begin{array}{l}\text { - Apply high-precision analyses of U isotope ratios } \\
\text { to pinpoint sources of } \mathrm{VZ} \text { and } \mathrm{GW} \text { plumes. } \\
\text { - Note appreciable past published work. }\end{array}$ \\
\hline \multirow{2}{*}{$\begin{array}{l}\text { Nature of the DVZ Threat: Breakthrough to } \\
\text { groundwater (GW) in mid-1990s with current } \\
\text { peak concentration } \sim 5,000 \mu \mathrm{g} / \mathrm{L}(>100 \text { times } \\
\text { drinking water standard). B Complex concep- } \\
\text { tual model (Serne et al. } 2010 \text { ) estimates } \sim 1,500 \\
\text { kgs of U within } 90 \mathrm{ft} \text { of aquifer while U mass } \\
\text { currently in GW is } 22 \mathrm{kgs} \text {. Remaining DVZ } \\
\text { mobile U inventory poses a significant and } \\
\text { immediate threat to groundwater. }\end{array}$} & $\begin{array}{c}\text { Predictive } \\
\text { Modeling } \\
\text { and } \\
\text { Data Integration } \\
\end{array}$ & - Develop reactive transport behavior models. \\
\hline & Remedial Design & $\begin{array}{l}\text { - Extract perched water. } \\
\text { - Evaluate long-term performance of surface } \\
\text { barriers. }\end{array}$ \\
\hline $\begin{array}{l}\text { Current Status: } 200-\mathrm{DV}-1 \text { Work Plan under } \\
\text { development may include BX-102 DVZ com- } \\
\text { ponent within scope of subsequent RI/FS. } \\
\text { WMA B-BX-BY corrective action is not cur- } \\
\text { rently scheduled (10+ years in future). Extrac- } \\
\text { tion of perched water containing uranium is } \\
\text { underway. Related treatability test for underly- } \\
\text { ing aquifer to occur in } 2012 \text {. DVZ treatability } \\
\text { testing contingent on results from U sequestra- } \\
\text { tion testing at U cribs. }\end{array}$ & $\begin{array}{l}\text { In Situ } \\
\text { Characterization } \\
\text { and Monitoring }\end{array}$ & $\begin{array}{l}\text { - Monitor site through routine environmental } \\
\text { sampling. } \\
\text { - VZ monitoring using extracted perched water. }\end{array}$ \\
\hline
\end{tabular}

\begin{tabular}{|c|c|}
\hline \multicolumn{2}{|c|}{ Schedule } \\
\hline $\begin{array}{c}\text { M-15-110A } \\
\text { Submit 200-DV-1 Work Plan } \\
\text { 9/30/2012 }\end{array}$ & $\begin{array}{c}\text { M-15-110B } \\
\text { Submit 200-DV-1 RFI/CMS } \\
\text { 9/30/2015 }\end{array}$ \\
\hline Operable Unit & 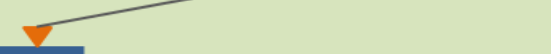 \\
\hline $\begin{array}{l}\text { Perched Water Extraction } \\
\text { Uranium Sequestration Test } \\
\text { BP-5 GW Treatability Test } \\
\text { Additional VZ Treatability Test }\end{array}$ & $\begin{array}{l}\text { WMA B-BX-BY Corrective Action } \\
\text { and Closure Milestones - TBD }\end{array}$ \\
\hline
\end{tabular}




\section{Deep Vadose Zone Challenge: B Complex Technetium}

\begin{tabular}{|c|c|c|}
\hline Nature of the Problem & & Current Activities \\
\hline $\begin{array}{l}\text { Site Description: BY Cribs consist of eight } \\
\text { cribs north of and adjacent to BY Farm. Seven } \\
\text { of these cribs received tri-butyl phosphate waste } \\
\left(\sim 9 \mathrm{Mgal} \text { and } 130 \mathrm{Ci} \text { of }{ }^{99} \mathrm{Tc}\right) \text { in } 1954-55 \text {. Dis- } \\
\text { charge discontinued when breakthrough to GW } \\
\text { detected in } 1955 \text {. Responsible for } 90 \% \text { of }{ }^{99} \mathrm{Tc} \\
\text { released in the B Complex region that includes } \\
\mathrm{B}-\mathrm{BX}-\mathrm{BY} \text { tank farms, B-7A and B cribs, and } \\
\mathrm{B}-8 \text { crib. }\end{array}$ & $\begin{array}{l}\text { Controlling } \\
\text { Processes }\end{array}$ & $\begin{array}{l}\text { - Fundamental science investigations of the redox } \\
\text { state and Tc reactivity in a variety of Hanford } \\
\text { vadose and saturated zone sediments. }\end{array}$ \\
\hline \multirow{2}{*}{$\begin{array}{l}\text { Nature of the DVZ Threat: Breakthrough to } \\
\mathrm{GW} \text { in } 1955 \text { with continuing impact to } \mathrm{GW} \text { to } \\
\text { present. Current peak concentration } \sim 100,000 \\
\text { pCi/L-more than } 100 \text { times above drinking } \\
\text { water standard. B Complex conceptual model } \\
\text { (Serne et al. 2010) estimates as much as } 55 \mathrm{Ci} \\
\text { of }{ }^{99} \mathrm{Tc} \text { remains in DVZ. Remaining DVZ }{ }^{99} \mathrm{Tc} \\
\text { inventory poses a significant and immediate } \\
\text { threat to GW quality. }\end{array}$} & $\begin{array}{c}\text { Predictive } \\
\text { Modeling and } \\
\text { Data Integration }\end{array}$ & - Develop reactive transport behavior models. \\
\hline & Remedial Design & $\begin{array}{l}\text { - Evaluate long-term performance of surface } \\
\text { barriers. }\end{array}$ \\
\hline $\begin{array}{l}\text { Current Status: 200-DV-1 Work Plan under } \\
\text { development includes BY Cribs and other non- } \\
\text { tank farm waste sites in this region within the } \\
\text { scope of subsequent RI/FS. A treatability test } \\
\text { for underlying aquifer to occur in } \sim 2012 \text {. DVZ } \\
\text { treatability testing contingent on results from U } \\
\text { sequestration testing at BC Cribs and Trenches. }\end{array}$ & $\begin{array}{l}\text { In Situ } \\
\text { Characterization } \\
\text { and Monitoring }\end{array}$ & $\begin{array}{l}\text { - Monitor site through routine environmental } \\
\text { sampling. }\end{array}$ \\
\hline
\end{tabular}

\begin{tabular}{|c|c|}
\hline \multicolumn{2}{|c|}{ Schedule } \\
\hline $\begin{array}{l}\text { M-15-110A } \\
\text { Submit 200-DV-1 Work Plan } \\
9 / 30 / 2012\end{array}$ & $\begin{array}{c}\text { M-15-110B } \\
\text { Submit 200-DV-1 RFI/CMS } \\
\text { 9/30/2015 }\end{array}$ \\
\hline $\begin{array}{l}\text { 200-DV-1 } \\
\text { Operable Unit }\end{array}$ & \\
\hline $\begin{array}{l}\text { Perched Water Extraction } \\
\text { Uranium Sequestration Test } \\
\text { BP-5 GW Treatability Test } \\
\text { Additional VZ Treatability Test }\end{array}$ & $\begin{array}{l}\text { WMA B-BX-BY Corrective Action } \\
\text { and Closure Milestones - TBD }\end{array}$ \\
\hline
\end{tabular}




\section{Deep Vadose Zone Challenge: Waste Management Area C}

\begin{tabular}{|c|c|c|}
\hline Nature of the Problem & & Current Activities \\
\hline $\begin{array}{l}\text { Site Description: WMA C consists of twelve } \\
100 \text {-series SSTs and four } 200 \text { series SSTs used } \\
\text { from } 1946 \text { to } 1978 \text {. Tanks received a very } \\
\text { diverse set of waste streams. Includes highly } \\
\text { complex transfer system, including pipelines, } \\
\text { diversion boxes, vaults, etc. Seven tanks desig- } \\
\text { nated as suspected leakers. Multiple releases to } \\
\text { soil from transfer system components. }\end{array}$ & $\begin{array}{l}\text { Controlling } \\
\text { Processes }\end{array}$ & \\
\hline \multirow{2}{*}{$\begin{array}{l}\text { Nature of the DVZ Threat: Threat to ground- } \\
\text { water appears dominated by past releases from } \\
\text { waste transfer system components. Total inven- } \\
\text { tory of } \sim 6 \mathrm{Ci} \text { of }{ }^{99} \mathrm{Tc} \text { estimated within soil } \\
\text { (Corbin et al. } 2005 \text { ). A small }{ }^{99} \mathrm{Tc} \text { groundwater } \\
\text { plume recently emerged beneath and to the } \\
\text { southwest of the farm with a peak concentration } \\
\text { of } 18,000 \mathrm{pCi} / \mathrm{L}(20 \text { times drinking water stan- } \\
\text { dard). Exact source of this plume from within } \\
\text { WMA C is unknown. }\end{array}$} & $\begin{array}{c}\text { Predictive } \\
\text { Modeling and } \\
\text { Data Integration }\end{array}$ & - Develop reactive transport behavior models. \\
\hline & Remedial Design & $\begin{array}{l}\text { - Evaluate long-term performance of surface } \\
\text { barriers. }\end{array}$ \\
\hline $\begin{array}{l}\text { Current Status: WMA C is targeted as first } \\
\text { WMA to complete tank waste retrieval, correc- } \\
\text { tive action, and closure. An RFI/CMS underway } \\
\text { to assess threat from soil contamination and to } \\
\text { evaluate possible corrective actions. Extensive } \\
\text { field characterization underway. Leak assess- } \\
\text { ment and post-retrieval risk assessments will } \\
\text { continue to refine soil inventory estimate and } \\
\text { threat to the environment. Corrective action and } \\
\text { closure work schedule to be complete in } 2019 \text {. }\end{array}$ & $\begin{array}{c}\text { In Situ } \\
\text { Characterization } \\
\text { and Monitoring }\end{array}$ & $\begin{array}{l}\text { - Monitor site through routine environmental } \\
\text { sampling. }\end{array}$ \\
\hline
\end{tabular}

\begin{tabular}{|c|c|c|c|}
\hline \multicolumn{4}{|c|}{ Schedule } \\
\hline $\begin{array}{l}\text { M-45-61 } \\
\text { Submit WMAC RFI/CM } \\
12 / 31 / 2014 \\
\text { WMA C Corrective } \\
\text { Action Milestones }\end{array}$ & $\begin{array}{c}\text { M-45-62 } \\
\text { Submit WMAC Corr } \\
\text { MS Measures Implemen } \\
\text { Plan } \\
6 / 30 / 2015\end{array}$ & $\begin{array}{l}\text { ective } \\
\text { tation }\end{array}$ & \\
\hline $\begin{array}{c}\text { M-45-81 } \\
\text { Implement \& Complete C-200 } \\
\text { Closure Demo Plan } \\
\text { 09/30/2014 }\end{array}$ & $\begin{array}{c}M-45-82 \\
\text { Submit Permit Mod to } \\
\text { Support WMA C Closure } \\
\text { 09/30/2015 }\end{array}$ & $\begin{array}{l}\text { WMA C Closure } \\
\text { Milestones }\end{array}$ & $\begin{array}{c}\text { M-45-83 } \\
\text { Complete closure } \\
\text { of WMAC } \\
6 / 30 / 2019 \\
\end{array}$ \\
\hline
\end{tabular}




\section{Deep Vadose Zone Challenge: T Complex}

\begin{tabular}{|c|c|c|}
\hline Nature of the Problem & & Current Activities \\
\hline $\begin{array}{l}\text { Site Description: T Complex consists of SST } \\
\text { farms T, TX, and TY and adjacent cribs and } \\
\text { trenches }-17 \text { of which are assigned to the } \\
200-D V-1 \text { operable unit. Corbin et al. }(2005) \\
\text { estimates } \sim 50 \mathrm{Ci} \text { of }{ }^{99} \mathrm{Tc} \text {. Tank T-106 responsible } \\
\text { for largest release with } 37 \mathrm{Ci} \text { of }{ }^{99} \mathrm{Tc} \text {. Depth to } \\
\text { groundwater } 270 \mathrm{ft} \text { with a significant caliche } \\
\text { layer (Cold Creek Unit [CCU]) at depth of } \sim 100 \mathrm{ft} \\
\text { that retards vertical flow of moisture. Several } \\
\text { commingled VZ and GW plumes exist. }\end{array}$ & $\begin{array}{l}\text { Controlling } \\
\text { Processes }\end{array}$ & $\begin{array}{l}-\mathrm{U}(\mathrm{VI}) \text { reactivity in and the physicochemical } \\
\text { properties of the CCU beneath TX-104. }\end{array}$ \\
\hline \multirow{2}{*}{$\begin{array}{l}\text { Nature of the DVZ Threat: In } 2007,{ }^{99} \mathrm{Tc} \\
\text { northeast of T Farm reached a peak concentra- } \\
\text { tion of } 180,000 \mathrm{pCi} / \mathrm{L}(200 \text { times drinking } \\
\text { water standard). Two extraction wells place } \\
\text { into service in September } 2007 \text { to contain } \\
\text { plume spread. Less concentrated plumes of Cr } \\
\text { also originate in this area. High concentrations } \\
\text { of }{ }^{99} \mathrm{Tc} \text { pore water found on top of the CCU. }\end{array}$} & $\begin{array}{c}\text { Predictive } \\
\text { Modeling and } \\
\text { Data Integration }\end{array}$ & - Develop reactive transport behavior models. \\
\hline & Remedial Design & $\begin{array}{l}\text { - Evaluate long-term performance of surface } \\
\text { barriers. }\end{array}$ \\
\hline $\begin{array}{l}\text { Current Status: T Complex overlies the } \\
200-\mathrm{ZP}-1 \text { groundwater operable unit that will } \\
\text { undergo GW treatment starting in } 2012 \text { with } \\
\text { treatment targeting } \mathrm{CCl}_{4} \text { and other contaminants } \\
\text { including }{ }^{99} \mathrm{Tc} \text {. Two interim infiltration barriers } \\
\text { have been installed over four tanks in T Farm } \\
\text { and six tanks in TY Farm. } 200-\mathrm{DV}-1 \text { is develop- } \\
\text { ing conceptual models for the T Complex and } \\
\text { will conduct RI/FS for waste sites. T, TX, and } \\
\text { TY corrective action and closure not currently } \\
\text { scheduled, }(10+\text { years in future.) }\end{array}$ & $\begin{array}{c}\text { In Situ } \\
\text { Characterization } \\
\text { and Monitoring }\end{array}$ & $\begin{array}{l}\text { - Monitor site through routine environmental } \\
\text { sampling. }\end{array}$ \\
\hline
\end{tabular}

\begin{tabular}{|c|c|}
\hline \multicolumn{2}{|c|}{ Schedule } \\
\hline $\begin{array}{l}\text { M-15-110A } \\
\text { Submit 200-DV-1 Work Plan } \\
\text { 9/30/2012 }\end{array}$ & $\begin{array}{c}\text { M-15-110B } \\
\text { Submit } 200-\mathrm{DV}-1 \mathrm{RFI} / \mathrm{CMS} \\
\text { 9/30/2015 }\end{array}$ \\
\hline Operable Unit & \\
\hline $\begin{array}{l}\text { Treatability Testing: } \\
\text { Desiccation Pilot Test } \\
\text { Pore Water Extraction Test }\end{array}$ & $\begin{array}{l}\text { WMA T, TX-TY Corrective Action } \\
\text { and Closure Milestones - TBD }\end{array}$ \\
\hline
\end{tabular}




\section{Deep Vadose Zone Challenge: U Cribs}

\begin{tabular}{|c|c|c|}
\hline Nature of the Problem & & Current Activities \\
\hline $\begin{array}{l}\text { Site Description: Several cribs south of U Plant } \\
\text { (particularly U-8 and U-12). Sites received } \\
\sim 140 \text { million gals of contaminated process } \\
\text { steam condensate from uranium recovery } \\
\text { processes. Corbin et al. (2005) estimates } \\
32,000 \text { kgs of uranium discharged to these } \\
\text { sites. Depth to groundwater } \sim 260 \mathrm{ft} \text { and caliche } \\
\text { layer (CCU) about } 180 \text { feet deep. }\end{array}$ & $\begin{array}{c}\text { Controlling } \\
\text { Processes }\end{array}$ & $\begin{array}{l}\text { - Fundamental science investigations of the iden- } \\
\text { tity of controlling phases for uranium-transport } \\
\text { behavior and fate in a variety of Hanford vadose } \\
\text { sediments. }\end{array}$ \\
\hline \multirow{2}{*}{$\begin{array}{l}\text { Nature of the DVZ Threat: These sites lack } \\
\text { sufficient characterization to assess their threat to } \\
\text { groundwater. Uranium exhibits highly variable } \\
\text { behavior in the subsurface at Hanford. There } \\
\text { appears to be very little, if any, breakthrough to } \\
\text { groundwater from these sites to date. There is } \\
\text { an underlying U and }{ }^{99} \mathrm{Tc} \text { groundwater plume } \\
\text { that is undergoing interim action treatment. }\end{array}$} & $\begin{array}{c}\text { Predictive } \\
\text { Modeling and } \\
\text { Data Integration }\end{array}$ & - Develop reactive transport behavior models. \\
\hline & Remedial Design & $\begin{array}{l}\text { - Extract perched water. } \\
\text { - Evaluate long-term performance of surface } \\
\text { barriers. }\end{array}$ \\
\hline $\begin{array}{l}\text { Current Status: Supplemental characterization } \\
\text { planned for 2011-12 (DOE-RL 2010). Field } \\
\text { testing of U sequestration methods using ammo- } \\
\text { nia gas planned for 2012-13 (Szecsody et al. } \\
2010 \text { ). Groundwater remediation expected to } \\
\text { be provided by the } 200 \text { West Groundwater } \\
\text { Treatment System assuming the } 200-U P-1 \\
\text { ROD supports this approach. }\end{array}$ & $\begin{array}{l}\text { In Situ } \\
\text { Characterization } \\
\text { and Monitoring }\end{array}$ & $\begin{array}{l}\text { - Monitor site through routine environmental } \\
\text { sampling. } \\
\text { - VZ monitoring using extracted perched water. }\end{array}$ \\
\hline
\end{tabular}

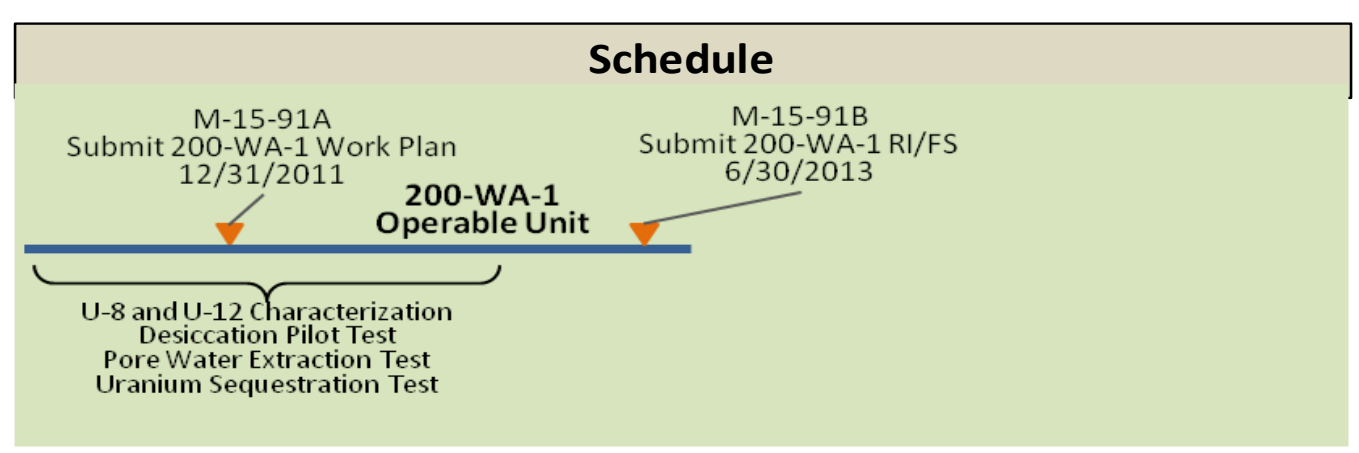




\section{Deep Vadose Zone Challenge: S Complex}

\begin{tabular}{|c|c|c|}
\hline Nature of the Problem & & Current Activities \\
\hline $\begin{array}{l}\text { Site Description: This area includes SSTs in } \\
\text { S Farm (12 tanks) and SX Farm (15 Tanks) } \\
\text { and several nearby waste sites, including 200- } \\
\text { DV-1 sites (216-S-21, 216-S-9, 216-S-13, and } \\
216-\mathrm{S}-14) \text {. }\end{array}$ & $\begin{array}{l}\text { Controlling } \\
\text { Processes }\end{array}$ & $\begin{array}{l}\text { - Significant past work by PNNL and Environ- } \\
\text { mental Management Science Program (EMSP) } \\
\text { researchers. }\end{array}$ \\
\hline \multirow{2}{*}{$\begin{array}{l}\text { Nature of the DVZ Threat: Tank waste leaked } \\
\text { from leaks in SX Farm has reached GW. Tech- } \\
\text { netium- } 99 \text { levels exceed } 100 \text { times drinking } \\
\text { water standard. Estimated soil inventory of } \\
{ }^{99} \mathrm{Tc} \text { is } \sim 40 \mathrm{Ci} \text { and impacts to GW predicted to } \\
\text { continue in the future (CHPRC 2002). Depth } \\
\text { to GW is } \sim 240 \mathrm{ft} \text {, and a caliche layer (CCU) } \\
\text { is present at a depth of } \sim 130 \mathrm{ft} \text {, which tends to } \\
\text { retard vertical migration of contaminants. Higher } \\
\text { concentrations of contaminants detected atop } \\
\text { this layer. }\end{array}$} & $\begin{array}{c}\text { Predictive } \\
\text { Modeling and } \\
\text { Data Integration } \\
\end{array}$ & - Develop reactive transport behavior models. \\
\hline & Remedial Design & $\begin{array}{l}\text { - Evaluate long-term performance of surface } \\
\text { barriers. }\end{array}$ \\
\hline $\begin{array}{l}\text { Current Status: S-SX Farms have complete } \\
\text { Phase } 1 \text { RCRA investigation, and an interim } \\
\text { infiltration barrier is being designed for installa- } \\
\text { tion in } 2012 \text { to mitigate impacts from past } \\
\text { releases. } 200-\mathrm{DV}-1 \text { is developing conceptual } \\
\text { models for the S Complex and will conduct RI/ } \\
\text { FS for waste sites. S-SX corrective action and } \\
\text { closure not currently scheduled (10+ years in } \\
\text { the future). This region overlies } 200-\mathrm{UP}-1 \mathrm{GW} \\
\text { operable unit. A localized GW treatment system } \\
\text { is planned to address }{ }^{99} \mathrm{Tc} \text { plume south and east } \\
\text { of SX farm starting in } 2012 \text {. }\end{array}$ & $\begin{array}{l}\text { In Situ } \\
\text { Characterization } \\
\text { and Monitoring }\end{array}$ & $\begin{array}{l}\text { - Monitor site through routine environmental } \\
\text { sampling. }\end{array}$ \\
\hline
\end{tabular}

\begin{tabular}{|c|c|}
\hline \multicolumn{2}{|c|}{ Schedule } \\
\hline $\begin{array}{c}\text { M-15-110A } \\
\text { Submit 200-DV-1 Work Plan } \\
\text { 9/30/2012 }\end{array}$ & $\begin{array}{c}\text { M-15-110B } \\
\text { Submit 200-DV-1 RFI/CMS } \\
\text { 9/30/2015 }\end{array}$ \\
\hline $\begin{array}{l}\text { 200-DV-1 } \\
\text { Operable Unit }\end{array}$ & \\
\hline $\begin{array}{l}\text { Treatability Testing: } \\
\text { Desiccation Pilot Test } \\
\text { PoreWater Extraction Test } \\
\text { GW Extraction System }\end{array}$ & $\begin{array}{l}\text { WMA S-SX Corrective Action and } \\
\text { Closure Milestones - TBD }\end{array}$ \\
\hline
\end{tabular}




\section{References}

CHPRC - CH2M HILL Hanford Group, Inc. 2002. Field Investigation Report for Waste Management Area S-SX. RPP-7884, Rev. 0, CH2M HILL Hanford Group, Inc., Richland, Washington.

Corbin RA, BC Simpson, MJ Anderson, WF Danielson III, JG Field, TE Jones, and CT Kincaid. 2005. Hanford Soil Inventory Model Rev. 1. RPP-26744, Rev.0, CH2M HILL Hanford Group, Inc., Richland, Washington.

DOE-RL-U.S. Department of Energy, Richland Operations Office. 2010. 216-U-8 Crib and 216-U-12 Crib Vadose Zone Characterization Sampling and Analysis Plan. DOE/RL-2009-94, Revision 0, Richland, Washington.

Serne RJ, BN Bjornstad, JM Keller, PD Thorne, DC Lanigan, JN Christensen, and GS Thomas. 2010. Conceptual Models for Migration of Key Groundwater Contaminants Through the Vadose Zone and Into the Upper Unconfined Aquifer Below the B-Complex. PNNL-19277, Pacific Northwest National Laboratory, Richland, Washington.

Szecsody JE, MJ Truex, L Zhong, MD Williams, CT Resch, and JP McKinley. 2010. Remediation of Uranium in the Hanford Vadose Zone Using Gas-Transported Reactants: Laboratory Scale Experiments in Support of the Deep Vadose Zone Treatability Test Plan for the Hanford Central Plateau.

PNNL-18879, Pacific Northwest National Laboratory, Richland, Washington. 


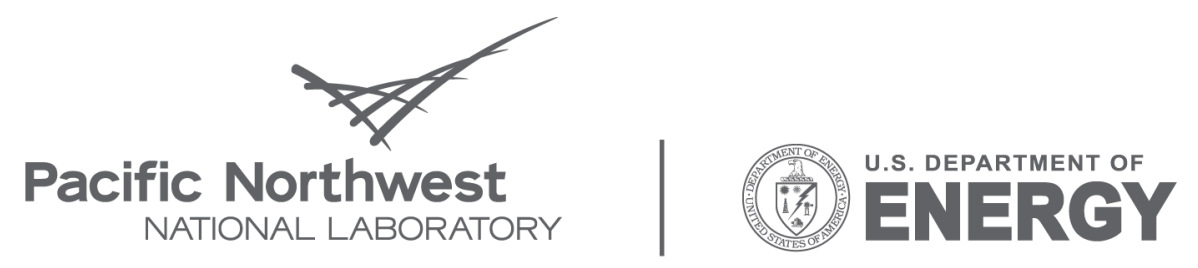

Proudly Operated by Battelle Since 1965

902 Battelle Boulevard

P.O. Box 999

Richland, WA 99352

1-888-375-PNNL (7665)

www.pnl.gov 